Prepared in cooperation with the King County Water and Land Resources Division

\title{
Effect of a Levee Setback on Aquatic Resources Using Two-Dimensional Flow and Bioenergetics Models
}

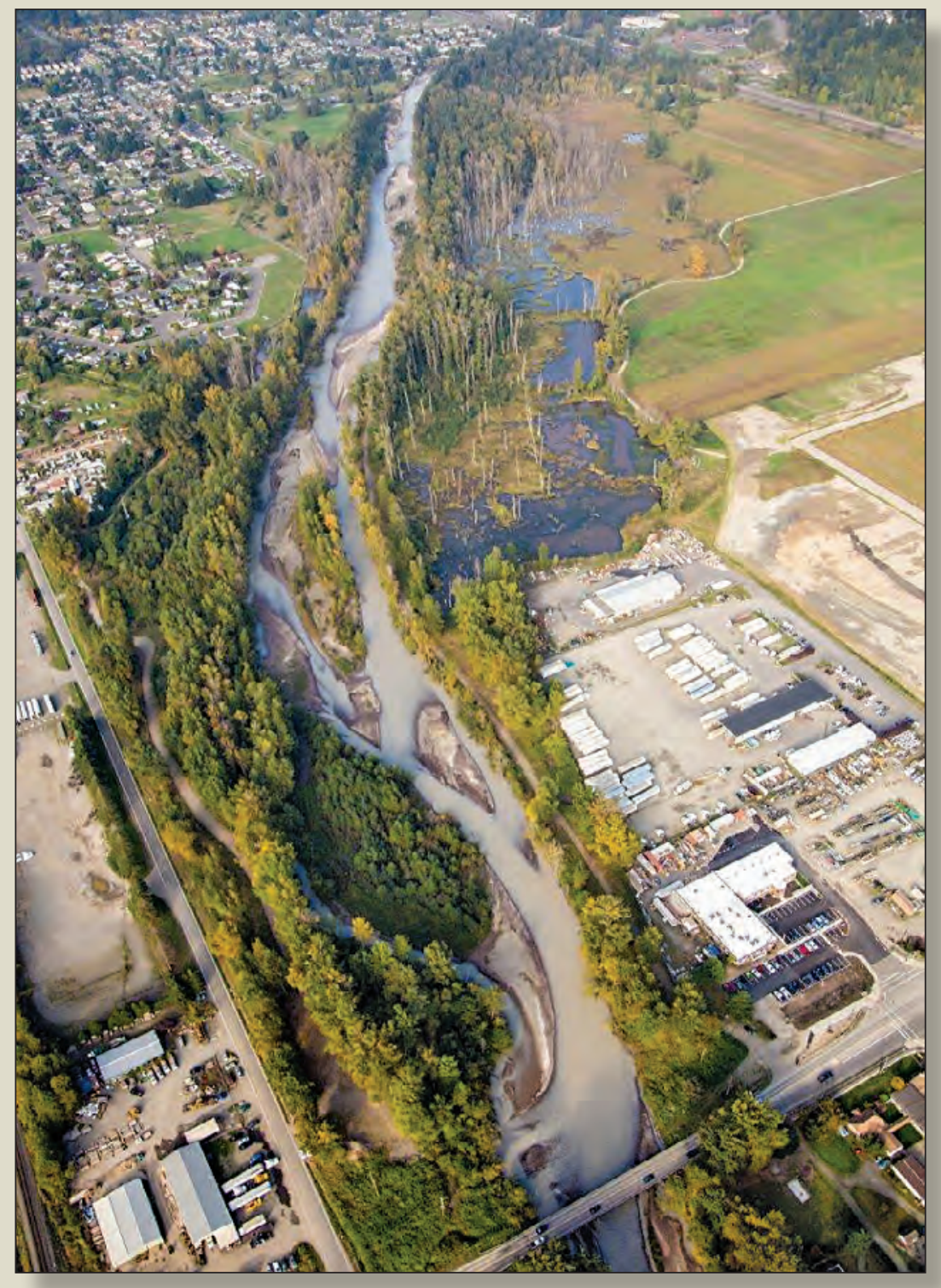

Scientific Investigations Report 2016-5025 
Cover: Photograph of aerial view of proposed levee setback project area on the White River near Pacific, Washington. (Photograph by Ned Ahrens, King County Department of Transportation, October 8, 2014. Used with permission.) 


\section{Effect of a Levee Setback on Aquatic Resources Using Two-Dimensional Flow and Bioenergetics Models}

By Robert W. Black, Christiana R. Czuba, Christopher S. Magirl, Sarah McCarthy, Hans Berge, and Kyle Comanor

Prepared in cooperation with the King County Water and Land Resources Division

Scientific Investigations Report 2016-5025 


\title{
U.S. Department of the Interior SALLY JEWELL, Secretary
}

\section{U.S. Geological Survey Suzette M. Kimball, Director}

\author{
U.S. Geological Survey, Reston, Virginia: 2016
}

For more information on the USGS - the Federal source for science about the Earth, its natural and living resources, natural hazards, and the environment—visit http://www.usgs.gov or call 1-888-ASK-USGS.

For an overview of USGS information products, including maps, imagery, and publications, visit http://www.usgs.gov/pubprod/.

Any use of trade, firm, or product names is for descriptive purposes only and does not imply endorsement by the U.S. Government.

Although this information product, for the most part, is in the public domain, it also may contain copyrighted materials as noted in the text. Permission to reproduce copyrighted items must be secured from the copyright owner.

Suggested citation:

Black, R.W., Czuba, C.R., Magirl, C.S., McCarthy, Sarah, Berge, Hans, and Comanor, Kyle, 2016, Effect of a levee setback on aquatic resources using two-dimensional flow and bioenergetics models: U.S. Geological Survey Scientific Investigations Report 2016-5025, 26 p., http://dx.doi.org/10.3133/sir20165025.

ISSN 2328-0328 (online) 


\section{Contents}

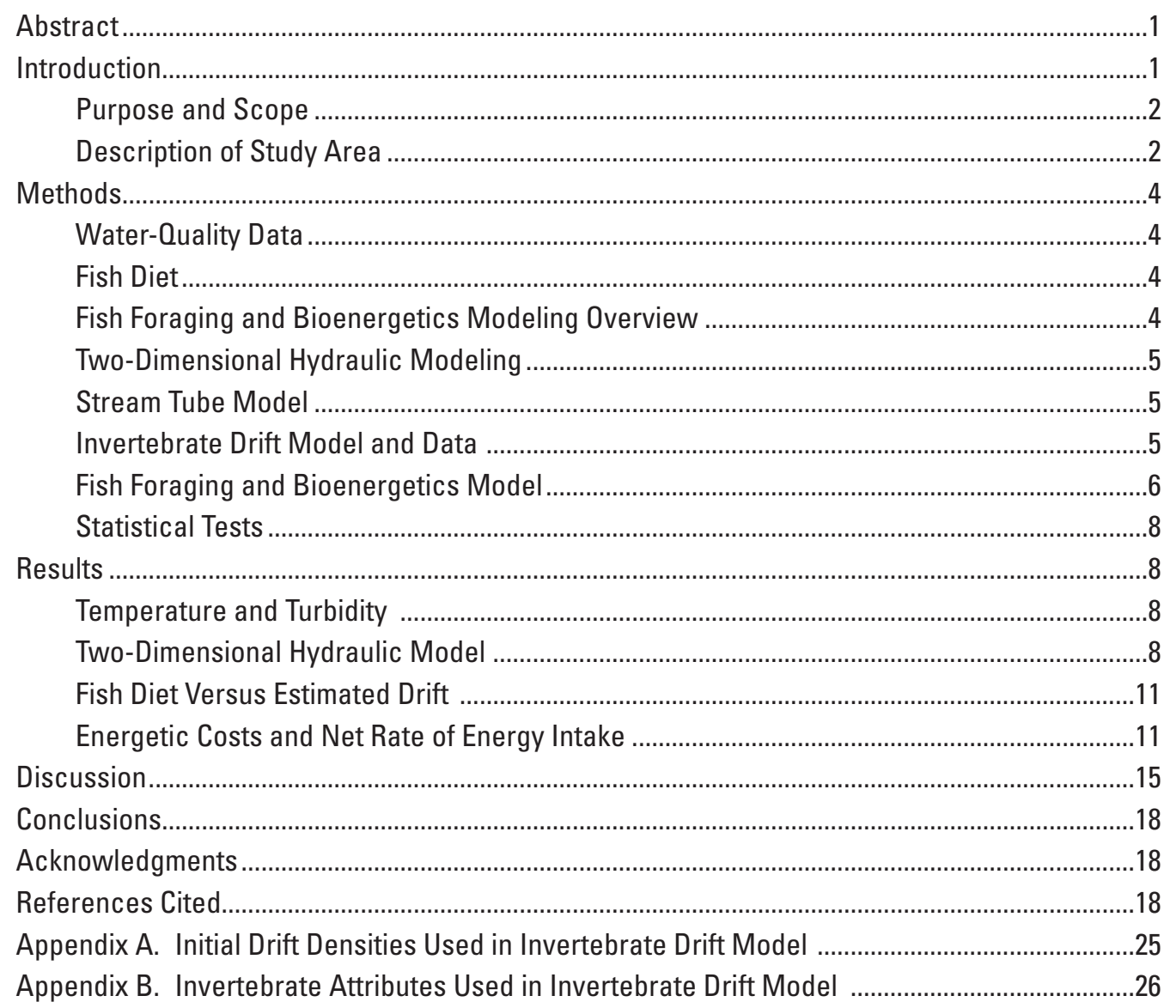




\section{Figures}

1. Orthographic map showing location of study area on White River near Pacific,

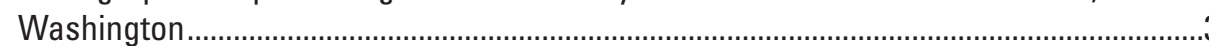

2. Modeling flow chart showing specific models and description of their outcome ............4

3. Graphs showing percentage distributions of modeled depths for flows of 25.9 and 49.3 cubic meters per second in study reach, White River near Pacific, Washington.....9

4. Graphs showing percentage distributions of modeled velocities for flows of 25.9 and 49.3 cubic meters per second, in study reach, White River near Pacific, Washington

5. Graph showing percentage of consumed prey taxa in estimated drift samples and seasonal stomach samples of juvenile salmonids in study reach, White River near Pacific, Washington

6. Boxplot showing modeled energetic costs summarized for each season and management condition for flows of 25.9 and 49.3 cubic meters per second in study reach, White River near Pacific, Washington

7. Graphs showing percentage abundance of modeled energetic costs summarized within four groups from lowest to highest costs for current and future conditions by season for flows of 25.9 and 49.3 cubic meters per second in study reach, White River near Pacific, Washington

8. Graphs showing modeled maximum, median, and minimum net rate of energy intake summarized for each season and management combination for flows of 25.9 and 49.3 cubic meters per second in study reach, White River near Pacific, Washington

9. Graphs showing percent abundance of modeled positive net rate of energy intake positions within the study reach under current and future conditions for flows of 25.9 and 49.3 cubic meters per second in study reach, White River near Pacific, Washington

\section{Tables}

1. Fish and water-quality characteristics used in the foraging model

2. Daily water temperature and turbidity for various flows by season at upstream boundary of study reach, May 2010-September 2012. 


\section{Conversion Factors}

Inch/Pound to International System of Units

\begin{tabular}{lcc}
\hline Multiply & By & To obtain \\
\hline cubic foot per second $\left(\mathrm{ft}^{3} / \mathrm{s}\right)$ & Flow rate & \\
\hline & 0.02832 & cubic meter per second $\left(\mathrm{m}^{3} / \mathrm{s}\right)$ \\
\hline ton per year (ton $/ \mathrm{yr})$ & Mass & \\
\hline
\end{tabular}

Temperature in degrees Fahrenheit $\left({ }^{\circ} \mathrm{F}\right)$ may be converted to degrees Celsius $\left({ }^{\circ} \mathrm{C}\right)$ as ${ }^{\circ} \mathrm{C}=\left({ }^{\circ} \mathrm{F}-32\right) / 1.8$.

International System of Units to Inch/Pound

\begin{tabular}{|c|c|c|}
\hline Multiply & By & To obtain \\
\hline \multicolumn{3}{|c|}{ Length } \\
\hline centimeter $(\mathrm{cm})$ & 0.3937 & inch (in.) \\
\hline meter $(\mathrm{m})$ & 3.281 & foot $(\mathrm{ft})$ \\
\hline \multicolumn{3}{|c|}{ Volume } \\
\hline cubic meter $\left(\mathrm{m}^{3}\right)$ & 35.31 & cubic foot $\left(\mathrm{ft}^{3}\right)$ \\
\hline \multicolumn{3}{|c|}{ Flow rate } \\
\hline cubic meter per second $\left(\mathrm{m}^{3} / \mathrm{s}\right)$ & 35.31 & cubic foot per second $\left(\mathrm{ft}^{3} / \mathrm{s}\right)$ \\
\hline $\begin{array}{l}\text { millimeter per year per meter } \\
\qquad[(\mathrm{mm} / \mathrm{yr}) / \mathrm{m}]\end{array}$ & 0.012 & inch per year per foot $[(\mathrm{in} / \mathrm{yr}) / \mathrm{ft}]$ \\
\hline \multicolumn{3}{|c|}{ Mass } \\
\hline $\operatorname{gram}(\mathrm{g})$ & 0.03527 & Ounce, avoirdupois (oz) \\
\hline \multicolumn{3}{|c|}{ Energy } \\
\hline joule $(\mathrm{J})$ & 0.0000002 & kilowatthour (kWh) \\
\hline
\end{tabular}

Temperature in degrees Celsius $\left({ }^{\circ} \mathrm{C}\right)$ may be converted to degrees Fahrenheit $\left({ }^{\circ} \mathrm{F}\right)$ as ${ }^{\circ} \mathrm{F}=\left(1.8 \times{ }^{\circ} \mathrm{C}\right)+32$.

\section{Datums}

Vertical coordinate information is referenced to the North American Vertical Datum of 1988 (NAVD 88).

Horizontal coordinate information is referenced to the North American Datum of 1983 (NAD 83).

Altitude, as used in this report, refers to distance above the vertical datum. 



\title{
Effect of a Levee Setback on Aquatic Resources Using Two-Dimensional Flow and Bioenergetics Models
}

\author{
By Robert W. Black', Christiana R. Czuba, ${ }^{1}$ Christopher S. Magirl, ${ }^{1}$ Sarah McCarthy ${ }^{2}$, Hans Berge, ${ }^{2}$ and \\ Kyle Comanor ${ }^{2}$
}

\section{Abstract}

Watershed restoration is the focus of many resource managers and can include a multitude of restoration actions each with specific restoration objectives. For the White River flowing through the cities of Pacific and Sumner, Washington, a levee setback has been proposed to reconnect the river with its historical floodplain to help reduce flood risks, as well as provide increased habitat for federally listed species of salmonids. The study presented here documents the use of a modeling framework that integrates two-dimensional hydraulic modeling with process-based bioenergetics modeling for predicting how changes in flow from reconnecting the river with its floodplain affects invertebrate drift density and the net rate of energy intake of juvenile salmonids. Modeling results were calculated for flows of 25.9 and 49.3 cubic meters per second during the spring, summer, and fall. Predicted hypothetical future mean velocities and depths were significantly lower and more variable when compared to current conditions. The abundance of low energetic cost and positive growth locations for salmonids were predicted to increase significantly in the study reach following floodplain reconnection, particularly during the summer. This modeling framework presents a viable approach for evaluating the potential fisheries benefits of reconnecting a river to its historical floodplain that integrates our understanding of hydraulic, geomorphology, and organismal biology.

\section{Introduction}

Starting in the mid-19th century, river management in Washington State, significantly altered rivers to promote development in the floodplain and reduce flood risk (Collins and others, 2003). These anthropogenic alterations; such as removal of large wood, meander cutoffs, channel straightening, levee construction, water withdrawals, riparian deforestation, and construction of flood-control dams, accomplished societal development goals but severely degraded the function of river aquatic ecosystems (Beechie and others, 1994; Montgomery and others, 1999; Ward and others, 1999; Sommer and others, 2001; Bernhardt and others, 2005; Stanford and others, 2005). Anthropogenic actions were particularly extensive along rivers in the Puget Lowland of western Washington, in many places isolating the mainstem rivers from floodplains that contained important side-channel and backwater habitat (National Research Council, 1996; Collins and others, 2003; Beechie and others, 2012). Such alterations were not exclusive to the Puget Lowland, but have and do occur worldwide. Tockner and Stanford (2002) have suggested that rivers and their associated floodplains are among the world's most highly altered ecosystems. The alterations of rivers in the Pacific Northwest receive particular attention because of their reduction of the quality and quantity of aquatic habitat, and concomitant impact on anadromous Pacific salmonids like Chinook salmon (Oncorhynchus tshawytscha), coho salmon (O. kisutch), chum salmon (O. keta), pink salmon (O. gorbuscha), and steelhead trout (O. mykiss). Of these species, Chinook salmon and Steelhead trout are listed as threatened (under the federal Endangered Species Act) in Puget Sound and surrounding watershed (Federal Register 64 FR 1999 and Federal Register 71 FR 2006), which incorporates the Puget Lowland. With effective restoration, Puget Lowland rivers have the potential to again provide diverse aquatic and terrestrial-habitat patches ideal for multiple life stages of salmon, their prey, and other aquatic and terrestrial organisms (Montgomery and others, 1999; Sommer and others, 2001; Roni and others, 2006).
${ }^{1}$ U.S. Geological Survey.

${ }^{2}$ King County Water and Land Resources Division. 
Multiple flood-control approaches have been used with varying degrees of success and ecological impact during the 20th century. Channel straightening and levee construction were used to speed the transport of water and sediment down river corridors and enable development in the floodplain. In sediment-laden rivers, gravel removal (dredging and bar scalping) was common in the middle 20th century to increase flood-conveyance capacity and lower the water-surface elevation during flood events (Prych, 1988; Collins and Dunne, 1989); however, gravel removal fell out of favor in the 1990s because of the negative effects on aquatic ecology (Kondolf and others, 2002). In rivers prone to aggradation, levee-setback projects, whereby levees are moved back from the river banks or removed entirely, are increasingly considered as a river-management tool to lower water-surface elevation during floods (Czuba and others, 2010; Pierce County, 2012; King County, 2013). Furthermore, the reconnection of these river reaches with parts of their historical floodplains has the potential to improve ecological function in critical fish-bearing rivers (Costanza and others, 1997; Amoros and Bornette, 2002; Brown, 2002; Buijse and others, 2002; Pess and others, 2005; Hall and others, 2007; Opperman and others, 2010; Beechie and others, 2012).

Although the intrinsic benefit of levee-setback projects is to partially restore connection of rivers with their floodplains (Hughes, 1997; Brown, 2002; Buijse and others, 2002; Richards and others, 2002; Rohde and others, 2006; Hall and others, 2007), few efforts have quantitatively examined the potential increase in ecological productivity from such projects. With the development and application of two-dimensional (2D) hydraulic and bioenergetics models, potential flood risk reduction and biological benefits of levee-setback projects can be examined. Until recently, the evaluation of potential fisheries response to river restoration and management projects have relied on flow and habitat based models. These models assume that preferred habitats are primarily determined by depth, velocity, and substrate and typically ignore the role of food supply and foraging behavior in habitat quality (Orth, 1987; Wills and others, 2006; Hayes and others, 2007; Rosenfeld and Ptolemy, 2012). Little work has been done to examine how the hydraulic and geomorphic outcomes from restoration efforts affect the foraging efficiency and energetic benefits of these types of projects to drift feeding fish (Copp, 1989; Junk and others, 1989; Stanford and others, 2002; Bellmore and others, 2012).

\section{Purpose and Scope}

The study presented here documents an integrated modeling framework for predicting how changes in river flows affect invertebrate drift density and the net rate of energy intake (NREI) of salmonids (Rutherford, 1994; Hanson and others, 1997; Hughes and others, 2003; Hayes and others, 2007) in a section of the White River near Pacific, Washington. Two flow scenarios were evaluated for this section of river under two river management conditions: (1) the current tightly confined condition within levees, and (2) a hypothetical future condition in which a levee on one side of the river was setback establishing more natural geomorphic conditions with floodplain connection. Rather than assessing changes in potential fish habitat based on preferences for physical conditions alone, the objectives of this study were to evaluate how potential future hydraulic conditions would affect the abundance of energetically favorable positions within the study reach for juvenile salmonids.

\section{Description of Study Area}

The White River in western Washington drains the northern flank of Mount Rainier (fig. 1), a 4,392-m glaciated active volcano in the Cascade Range. The White River carries a heavy sediment load of about 500,000 ton/yr sourced predominantly from Mount Rainier (Dunne, 1986; Czuba and others, 2012). Because of its glacial origins on Mount Rainer, the White River transports fine-grained glacial 'flour' that gives the river a whitish-gray color during the late summer. Czuba and others (2012) reported that 28,000 ton/yr of coarse sediment accumulated in the study reach (fig. 1) between 1984 and 2009 resulting in sometimes rapid increases in watersurface elevation at flood stage (Czuba and others, 2010).

Historically, the White River has undergone extensive channel alterations in the form of levee construction, bank protection, and gravel removal to reduce flood risks. As a result, the river has been narrowed and isolated from its extensive predevelopment floodplain, which in turn has dramatically reduced potential habitat for native anadromous salmonid species (Chinook salmon, coho salmon, chum salmon, pink salmon, sockeye salmon, bull trout, cutthroat trout, and steelhead trout) that use the White River Basin for spawning, incubation, rearing, and migration (Gustafson and others, 1997; Johnson and others, 1999; Good and others, 2005; Hard and others, 2007; Ford, 2011). In an effort to reduce flood risks and improve instream habitat, King County has proposed a levee-setback project along the southeastern bank of the study reach (fig. 1; Herrera Environmental and Northwest Hydraulic Consultants, 2011).

This study was conducted at the site of the proposed levee-setback, an approximately 3,500-m reach of the White River about $110 \mathrm{~km}$ downstream from Mount Rainier, near the town of Pacific, Washington. The levee-setback project would increase the distance between confining levees, currently about 60-90 m, to as wide as $400 \mathrm{~m}$ (fig. 1). Mean annual flow for 19 years of data collected at a U.S. Geological Survey streamgage (site No. 12100490) near the upstream boundary of the study reach is $25.9 \mathrm{~m}^{3} / \mathrm{s}\left(913 \mathrm{ft}^{3} / \mathrm{s}\right)$ (U.S. Geological Survey, 2015). However, the amount of water diverted from the White River nearly $25 \mathrm{mi}$ upstream of the study site was significantly reduced in 2004, so the mean annual flow for water years 2006-09 was $49.3 \mathrm{~m}^{3} / \mathrm{s}\left(1,740 \mathrm{ft}^{3} / \mathrm{s}\right)$. 


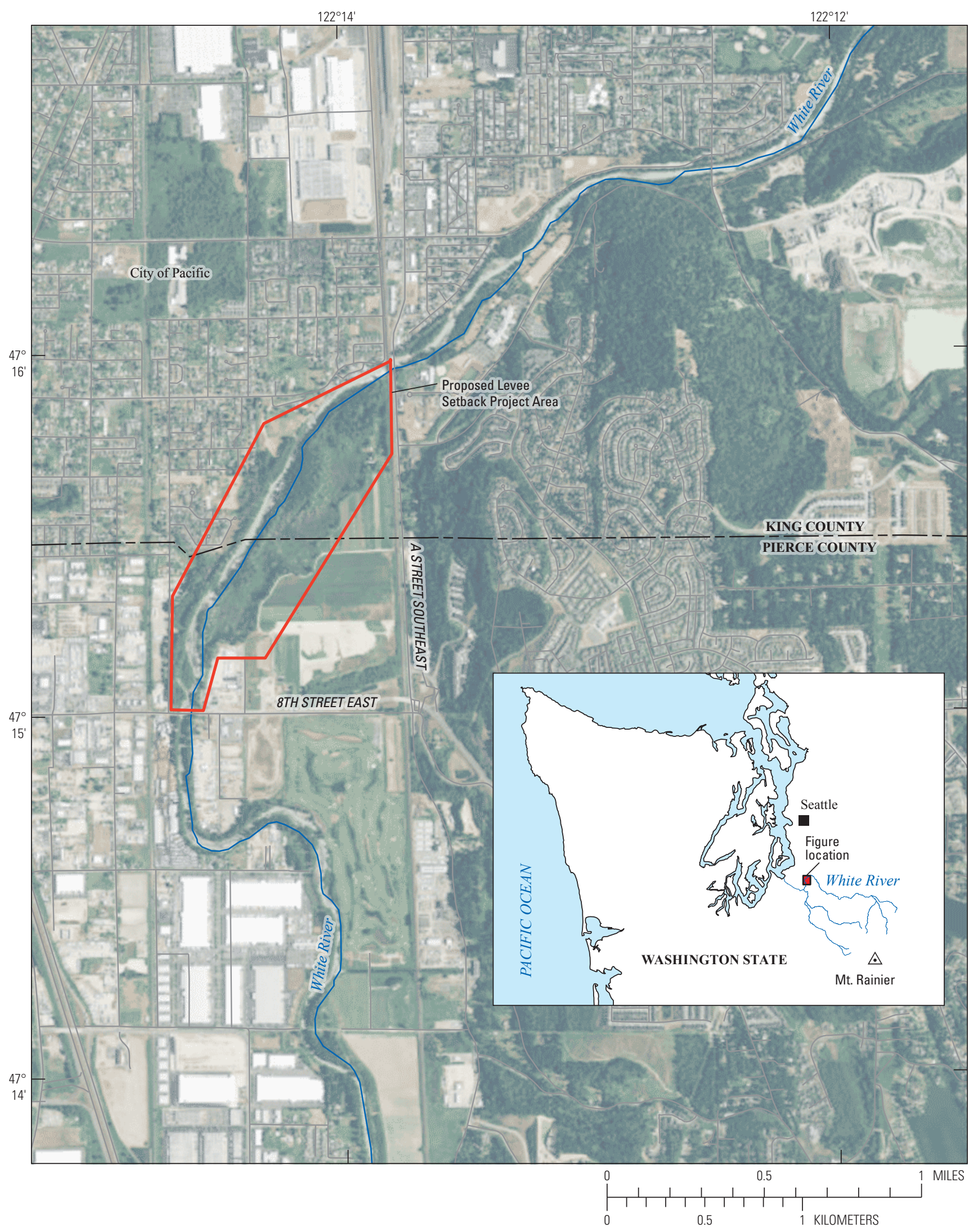

Figure 1. Location of study area on White River near Pacific, Washington. 


\section{Methods}

\section{Water-Quality Data}

Temperature and turbidity were continuously measured at hourly intervals from May 2010 to September 2012 at a site approximately $2 \mathrm{~km}$ upstream of the study reach, using a multi-parameter water-quality sonde. The sonde was calibrated prior to deployment, as described by Wagner and others (2006) and Gibs and others (2007), and checked for calibration every $1-2$ months. The turbidity sensor $\left(\mathrm{YSI}^{\circledR} 6136\right)$ was calibrated using a three-point calibration and standards of 0 , 10, and 1,000 formazin nephelometric turbidity units (FNU). Calibration and reporting procedures for turbidity also are discussed by Anderson (2005).

\section{Fish Diet}

During 2012, juvenile fish were sampled in the study reach once during each of three seasons: spring (March-May), summer (June-July) and fall (September-November) using beach seines. Fish were identified, weighed, and measured in the field. For each season, up to 10 fish were anesthetized with tricaine methanesulfonate and their stomach contents were evacuated by flushing with filtered native water following the methods of Foster (1977). Stomach contents were preserved in 90 percent ethanol in the field and were later identified to a taxonomic level comparable to the drift density taxonomic resolution used for this study.

\section{Fish Foraging and Bioenergetics Modeling Overview}

To predict how changes in river flows resulting from the proposed levee setback might affect the energetic costs and NREI of salmonids in the White River near Pacific, Washington, a number of hydraulic models and a fish foraging and bioenergetics model were used (Herrera Environmental Consultants and Northwest Hydraulic Consultants, 2011; Hayes and others, 2007; Kelly and others, 2012). The flow chart in figure 2 describes the models and the input data needed to determine the energetic costs and NREI at any

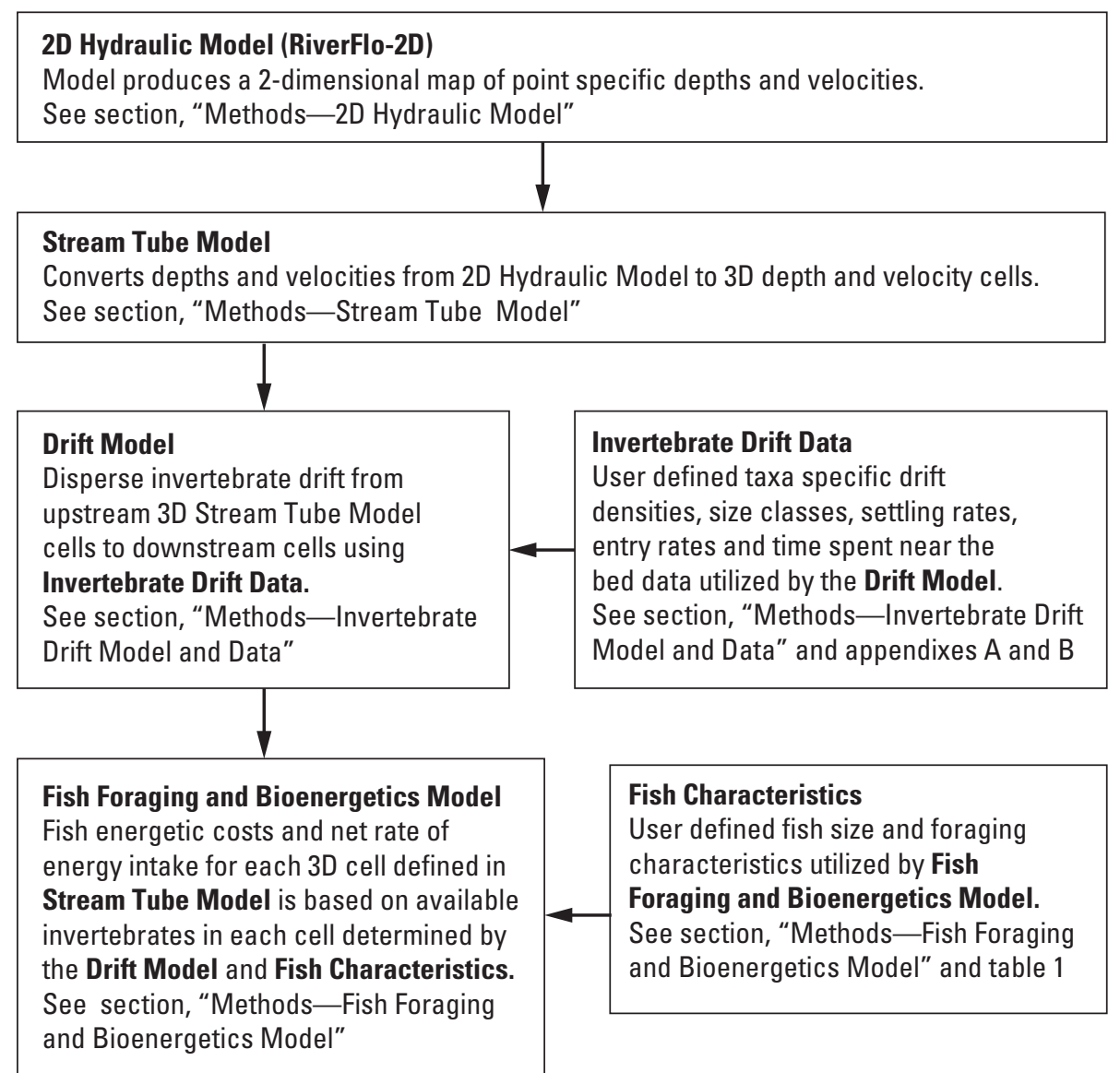

Figure 2. Specific models and description of their outcome. Model names are in bold text within the figure and within the document. Arrows identify the flow of model output from one model to the next. (2D, two-dimensional; 3D, three-dimensional) 
location within the study reach for juvenile salmonids under current and potential future conditions. For each node in the modeling flow chart, the specific location describing the modeling activity and/or the input data is identified. In general, a 2D Hydraulic Model was used to determine the depth and velocity characteristics for points throughout the study reach for current and future conditions under two user-defined discharge conditions. The 2D depth and velocity point measures were converted into a $3 \mathrm{D}$ representation of the study reach producing a series of cells distributed vertically and horizontally throughout the reach, each with a specific depth and velocity based on the Stream Tube Model. A data set of taxa-specific Invertebrate Drift Data densities and behavioral characteristics was used to disperse invertebrates from upstream Stream Tube Model cells to downstream cells using the Drift Model. Once the Drift Model "populates" each Stream Tube Model cell with invertebrate data, the Fish Foraging and Bioenergetics Model determines the energetic cost and NREI for each cell, based on user defined

Fish Characteristics and the depth, velocity, and invertebrate drift densities contained within each Stream Tube Model cell (fig. 2).

\section{Two-Dimensional Hydraulic Modeling}

Water-velocity and depth in the study reach under current and future (levee-setback) conditions were obtained from previously released 2D model simulations (Herrera Environmental Consultants and Northwest Hydraulic Consultants, 2011) completed using the commercial finite-element based RiverFLOW2D modeling package (Hydronia, 2015). The model domain for current conditions was constructed using lidar topography, total station surveys, and bathymetric data sets stitched together over the reach of interest. The model domain for the future conditions was created by modifying the current-condition topography to reflect (1) the proposed levee removal, (2) the new setback levee and engineered log structures, and (3) the new channels anticipated to form within the setback area, based on the hydraulic geometry of the existing channel and proxy examples from similar levee setback projects constructed within the region (Herrera Environmental Consultants and Northwest Hydraulic Consultants, 2011). The future conditions represent a reasonable best professional estimate based on experience and knowledge of the study area for the morphologic state of the river reach following the levee setback and several years (about 3 years) during which the river would equilibrate to its new floodplain conditions.

\section{Stream Tube Model}

The water-velocity and depth data from the 2D finite-element hydraulic models were first projected into a curvilinear orthogonal finite-difference grid using the International River Interface Cooperative software package
(International River Interface Cooperative, 2015). These interpolated orthogonal data were then used as input for the stream tube model described in detail by Hayes and others (2007) and Kelly and others (2012). The stream tube model takes the triangulated irregular network formatted output from the 2D hydraulic model and formats it as a series of user-defined cross sections, which are subdivided horizontally and vertically into an array of polygons that are connected with their corresponding polygons in adjacent cross sections to form tubes, each having equal proportions of the total flow (Kelly and others, 2012). The equal-discharge stream tubes provide a concise geometric description of water flow through the study reach (Hayes and others, 2007).

For this study, 2,691 user-defined cross sections spaced approximately every $1.4 \mathrm{~m}$ throughout the study reach were used for current and future conditions of flows of 25.9 and $49.3 \mathrm{~m}^{3} / \mathrm{s}$. The cross sections were perpendicularly divided into 20 user-defined equal discharge flow lines, and the resulting 2D flow polygons were vertically divided into 5 cells. For each vertical column of cells, the depth-averaged flow generated from the 2D hydraulic model was converted into pseudo 3D flows for individual cells assuming a logarithmic velocity profile as described by Gordon and others (1992). The final array of flow polygons for all models was composed of 269,000 cells.

\section{Invertebrate Drift Model and Data}

Drift-feeding, fish-bioenergetics models typically assume uniform drift densities which is known to be unrealistic (Stark and others, 2002). The array of depth and velocity polygons developed in the stream tube model provides a framework in which to model a more realistic dispersion of invertebrate drift in the study reach. For this study, the steady-state, drift-transport model developed by Hayes and others (2007) was used to predict drift densities for each stream tube cell or polygon by accounting for the dispersion of invertebrate drift between horizontal and vertical cells by moving from the upstream to the adjacent downstream cross section accounting for invertebrate settling and entry rates. Drift densities by taxa and size class are used by Hayes and others (2007) as model input at the upstream model boundary and are used for calculating densities at the next downstream cross section using the invertebrate dispersion approach developed by Ciborowski (1983a; 1983b; 1987) and the dispersion models of Rutherford (1994). The dispersion of each taxa and size class of invertebrate is based on a turbulent mixing model derived from an equation describing a Gaussian distribution where the standard deviation of lateral and vertical dispersion is predicated from water depth, velocity, and distance between cross sections. By integrating this equation twice, Hayes and others (2007) derive a model that predicts the drift contribution to adjacent downstream stream polygons based on upstream densities. Once dispersion is accounted for, the effects of taxa-specific settling and entry rates and time spent near the bed are used to adjust drift densities in each polygon. 
Effect of a Levee Setback on Aquatic Resources Using Two-Dimensional Flow and Bioenergetics Models

Drift settling is modeled as a linear, time-dependent process based on the knowledge of the drift concentrations at upstream cells. The drift entry component of the invertebrate dispersion model operates only on the concentrations of the bottom tier of polygons along the stream bed. For this study, settling and entry rates and time spent near the bed were derived from Elliott (2002), Hayes and others (2007), Kelly and others (2012), and Hayes and others (2012). A complete description of the invertebrate dispersion model can be found in Hayes and others (2007).

Invertebrate drift and size composition data specific to the study reach are not available. Given that the focus of this study was on the comparison between current and potential future conditions, site specific field measurements of drift densities were not required. Instead, estimates of invertebrate drift densities were developed from data published for sites with similar hydrologic, geographic, and geomorphic features to the study reach as reported in 10 studies (Ulfstrand, 1968; Martin and others, 1984; Gislason, 1985; Cellot, 1989, 1996; Meehan, 1996; Matthaei and others, 1997; Saltveit and others, 2001; Bureau of Reclamation, 2005; Clarke, 2007). An average total drift density in number per $\mathrm{m}^{3}$ was generated from these studies. The average percent drift density was proportionally distributed between different taxa and length classes based on percentage taxa composition and taxa specific length data generated by studies in the Skagit and Cedar Rivers in Washington (Gislason, 1985; R.W. Black, unpub. data, 2009). Published length and weight relationships were used to generate average weights for each taxa and length classes (Smock, 1980; Meyer, 1989; Johnston and Cunjak, 1999). Previous studies indicate that invertebrate drift densities can increase with increasing turbidity (Gammon, 1970; Ciborowksi and others, 1977; Rosenberg and Wiens, 1978; Ryan, 1991; Shaw and Richardson, 2001; Berry and others, 2003). To account for changes in drift densities in response to the measured seasonal changes in turbidity, the percentage change in drift densities in response to increasing turbidity measured by Gammon (1970) was used to modify the matrix of hypothetical drift densities for each season and simulated flow scenario. Although the turbidity and drift density relationship Gammon (1970) developed was based on laboratory controlled studies, we felt the controlled empirical relationship presented the most appropriate method for adjusting drift densities in a consistent and documentable approach. Future geomorphic conditions resulting from the proposed levee setback will likely influence the dynamics of turbidity in the river. The modeling effort presented here does not explicitly address future turbidity changes, but examines what the effect of the current levels of turbidity might have on fish energetics given the proposed setback. Input data required for each invertebrate drift modeling run included initial drift densities in each stream tube and polygon at the upstream cross section (appendix A). Taxa and size specific entry rates, settling velocities, and time spent near bed values were derived from Hayes and others (2012; appendix B).

\section{Fish Foraging and Bioenergetics Model}

The information on water depth and velocity calculated by the stream tube model and the taxa and size specific drift densities data calculated by the invertebrate drift model were used as input data to calculate fish energetic costs and NREI for current and future conditions for flows of 25.9 and $49.3 \mathrm{~m}^{3} / \mathrm{s}$. The foraging model is based on a model by Hughes and others (2003) which predicts the NREI of drift feeding fish from data on stream depth, velocity, drift taxa, and size composition, as well as information on the body size of fish and stream temperature to be modeled. NREI is derived from the gross rate of energy intake (GREI) minus the energetic cost to a fish of steady swimming to maintain a point within the modeling grid. The GREI for a fish at a particular location within the modeled reach is the summation of the capture rate for invertebrate prey within a size class and the energy content of that prey. It takes the form:

$$
\mathrm{GREI}=\sum_{i=1}^{N P} C R i P E A i
$$

where:

$$
\begin{aligned}
N P= & \text { number of invertebrate prey length classes. } \\
i= & \text { subscript designating prey length class. } \\
C R= & \text { capture rate for prey in length class } i \\
& \text { (number per second), and } \\
P E A= & \text { energy content (joules) of prey in length } \\
& \text { class } i .
\end{aligned}
$$

A complete description of the calculation of GREI can be found in Hughes and others (2003). To determine the energetic costs for a fish to maintain its position, the trout swimming cost model from the Fish Bioenergetics 3.0 model was used (Hanson and others, 1997). This model takes the form:

$$
R=\left(\left[(R A)(W R B)\left(e^{\left[\left(R Q_{1}\right)(T)\right]}\right)\left(e^{[(R T)(V E L)]}\right)\right](13,565)\right) / 86,400
$$

where:

$$
\begin{aligned}
R= & \text { swimming cost }(\mathrm{J} / \mathrm{s}) \text {. (In the above } \\
& \text { equation, a coefficient of } 13,565 \mathrm{~J} / \mathrm{g} \text { of } \\
& \text { oxygen }\left(\mathrm{O}^{2}\right) \text { is used to convert energy units } \\
& \text { to } \mathrm{J} / \mathrm{s}(\text { Elliott and Davidson, } 1975) \text { and } \mathrm{J} / \mathrm{d} \\
& \text { is converted to } \mathrm{J} / \mathrm{s} \text { by dividing by } 86,400, \\
R A= & \text { intercept of allometric mass function } \\
& \text { (i.e., specific weight of oxygen } \left.\left[\mathrm{gO}^{2} / \mathrm{g} / \mathrm{d}\right]\right) \\
& \text { consumed by } 1 \mathrm{~g} \text { fish at } 0^{\circ} \mathrm{C} \text { and zero } \\
& \text { swimming speed), } \\
W= & \text { fish weight }(\mathrm{g}), \\
R B= & \text { slope of allometric mass function for } \\
& \text { standard metabolism, } \\
R Q_{1}= & \text { water temperature dependent coefficient } \\
T= & \text { water temperature }\left({ }^{\circ} \mathrm{C}\right), \\
R T= & \text { coefficient for swimming speed } \\
& \text { dependence on metabolism }(\mathrm{s} / \mathrm{cm}), \text { and } \\
V E L= & \text { swimming speed }(\mathrm{m} / \mathrm{s}) .
\end{aligned}
$$


GREI, swimming costs, and NREI are calculated for a user specified number of evenly distributed points across each cross section characterized in the stream tube model. For this study, 36 interrogation points were distributed along each cross section. For each interrogation point, the cost of maintaining that point and the NREI were determined based on the previously described equations 1 and 2 .

The modeling framework presented in Hayes and others (2007) and Kelly and others (2012) was used to model fish foraging based on the model developed by Hughes and others (2003) that use the equations 1 and 2. Input requirements for this framework included the output from the drift model and fish characteristics that varied depending on season and levels of turbidity. Fish input characteristics for the foraging model (table 1) represent an estimate for a "typical" salmonid found in this system. Fish length, weight, and minimum and maximum prey size that fish could eat were based on the average weight and length of the fish captured for stomach analyses. These values as well as the height of the interrogation point off the bottom; number of interrogation points per cross-section; and defense radius were kept constant for model runs. Temperature values were based on average values for each season. Hughes and others (2003) found that drift feeding salmonids only captured an average of 55 percent of the drifting invertebrate prey items that entered their foraging stream tubes in relatively low turbid waters ( $<5 \mathrm{FNU})$. As noted previously, the White River is a glacial fed river and can be very turbid. It has been shown that an increase in sediment and turbidity can reduce the probability of prey detection by salmonids (Sigler and others, 1984; Sweka and Hartman, 2001a). To incorporate this knowledge into the modeling effort presented here, a reduction in the 55 percent prey capture efficiency measured by Hughes and others (2003) in waters with turbidity above 5 FNU was determined based on the average reduction in the rate of capture with increasing turbidity documented in the literature of Berg and Northcote (1985), Barrett and others (1992), Sweka and Harman (2001a, 2001b), and Harvey and White (2008). Rather than use an average of all of the capture efficiencies documented in the literature, we felt it was important to establish the 55 percent capture efficiency as the highest capture rate given that the modeling effort was based on Hughes and others (2003). Therefore, a maximum capture efficiency of 55 percent was established and proportionally lowered by an average reduction in capture efficiencies with increasing turbidity documented in Berg and Northcote (1985), Barrett and others (1992), Sweka and Harman (2001a, 2001b), and Harvey and White (2008). For each season-based turbidity measure, capture efficiencies were adjusted based on the approach described above (table 1).

Table 1. Fish and water-quality characteristics used in the foraging model.

[Season: Spring (March 21-June 20), Summer (June 21-September 21), Fall (September 22-December 20). Abbreviations: ${ }^{\circ} \mathrm{C}$, degrees Celsius; FNU, Formazin Nephelometric Unit; g, gram; $\mathrm{m}$, meter; $\mathrm{m}^{3} / \mathrm{s}$, cubic meter per second; mm, millimeter]

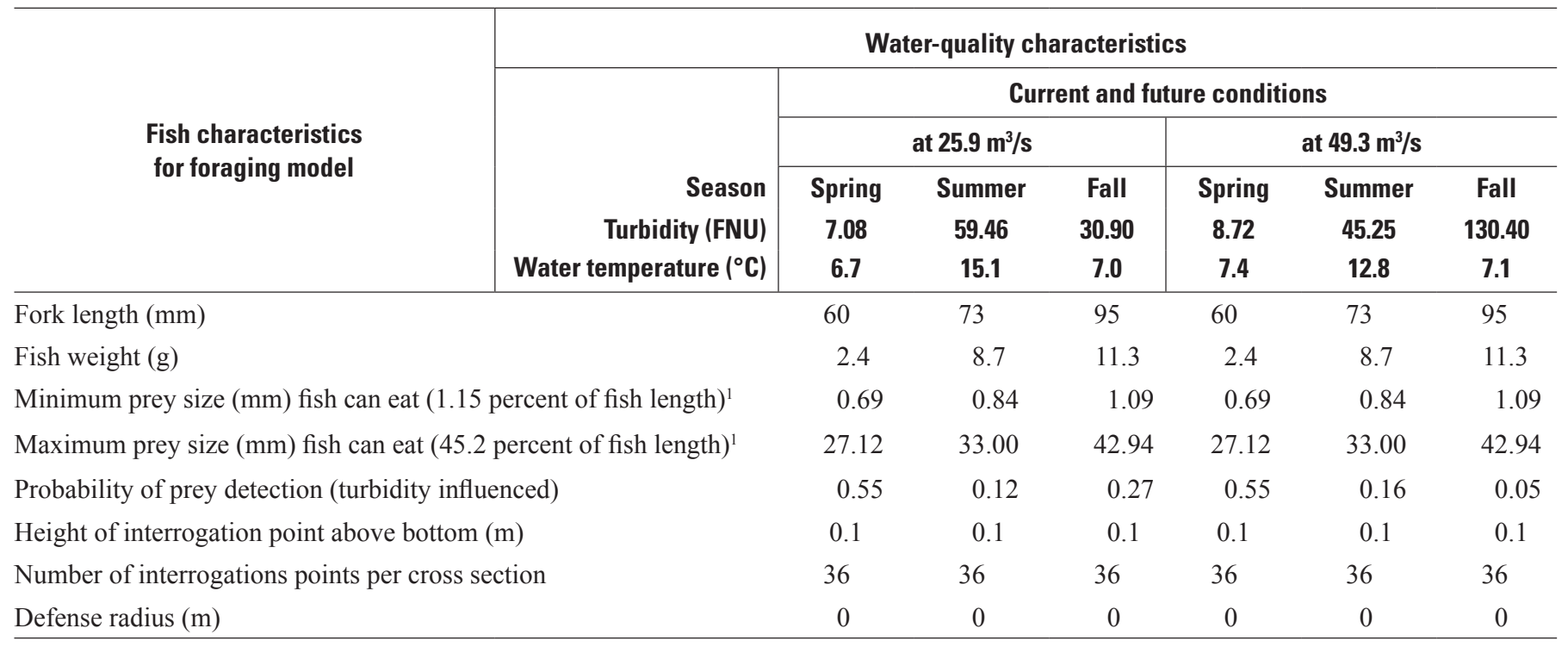

${ }^{1}$ Minimum and maximum prey size values based on Hughes and others (2003) and Hayes and others (2007). 


\section{Statistical Tests}

A rank-sum test was used to compare energetic cost or NREI values between current and future conditions for 25.9 and $49.3 \mathrm{~m}^{3} / \mathrm{s}$ for each season. In addition, energetic cost values were placed into one of four groups; $<0.01 \mathrm{~J} / \mathrm{s}$, $0.01-0.1 \mathrm{~J} / \mathrm{s}, 0.1-1 \mathrm{~J} / \mathrm{s}$, and $>1 \mathrm{~J} / \mathrm{s}$. A Chi-square test was used to compare the abundance of modeled output within each of these groups between current and future conditions for all season and both flows examined. NREI values were placed into groups of either negative or positive for current and future conditions and then compared by season and flow using Chi-square tests. All statistical analyses were done using Systat 13.0 (2009).

\section{Results}

\section{Temperature and Turbidity}

Hourly water temperature and daily turbidity data seasonally summarized from May 2010 to September 2012 were typical of a glacial fed river in the Pacific Northwest (table 2). Water temperatures were colder in the spring and fall, warmer in the summer, but never went above $20{ }^{\circ} \mathrm{C}$. The highest instantaneous temperature recorded was $19.6^{\circ} \mathrm{C}$ during the summer, while the lowest was $1.9^{\circ} \mathrm{C}$ during the fall. Water temperature and turbidity data were also seasonally summarized for data recorded at flows of 25.9 ( \pm 10 percent) and 49.3 ( \pm 10 percent $) \mathrm{m}^{3} / \mathrm{s}$. The interval for each of these flows was predefined to provide a representative range of temperatures and turbidity. Turbidity was substantially lower in the spring than other seasons for flows of $25.9( \pm 10$ percent) and $49.3\left( \pm 10\right.$ percent) $\mathrm{m}^{3} / \mathrm{s}$ (table 2$)$. The highest seasonal-mean turbidity of 130.40 FNU was measured in the fall for flows of $49.3 \mathrm{~m}^{3} / \mathrm{s}$ and the lowest was $7.08 \mathrm{FNU}$ measured in the spring for flows of $25.9 \mathrm{~m}^{3} / \mathrm{s}$. For both flow scenarios, the variability in turbidity was lowest during the spring and highest during the fall.

\section{Two-Dimensional Hydraulic Model}

The hydraulic modeling generated a series of geo-referenced depth and velocity grids for current and future conditions at flows of 25.9 and $49.3 \mathrm{~m}^{3} / \mathrm{s}$. For flows of $25.9 \mathrm{~m}^{3} / \mathrm{s}$, a significantly lower mean depth of $0.71 \mathrm{~m}$ was predicted for future conditions compared to a mean depth of $0.84 \mathrm{~m}$ for current conditions $(\mathrm{t}=28.5, \mathrm{p}<0.01$ ) (fig. $3 A$ ). For flows of $49.3 \mathrm{~m}^{3} / \mathrm{s}$, a similar significant $(\mathrm{t}=44.7, \mathrm{p}<0.01)$ decrease in mean depths between current conditions $(1.07 \mathrm{~m})$ and future conditions $(0.85 \mathrm{~m})$ was measured (fig. $3 B)$.

Table 2. Daily water temperature and turbidity for various flows by season at upstream boundary of study reach, May 2010-September 2012.

[Season: Spring (March 21-June 20), Summer (June 21-September 21), Fall (September 22 December 20). Abbreviations: ${ }^{\circ} \mathrm{C}$, degrees Celsius; FNU, Formazin Nephelometric Unit; $\mathrm{m} 3 / \mathrm{s}$, cubic meter per second; $\%$, percent]

\begin{tabular}{|c|c|c|c|c|c|c|}
\hline \multirow{2}{*}{ Season } & \multicolumn{3}{|c|}{ Daily temperature $\left({ }^{\circ} \mathrm{C}\right)$} & \multicolumn{3}{|c|}{ Daily turbidity (FNU) } \\
\hline & Mean & Maximum & Median & Mean & Maximum & Median \\
\hline \multicolumn{7}{|c|}{ All flows } \\
\hline Spring & 8.4 & 13.0 & 3.4 & 26.9 & 500.0 & 1.8 \\
\hline Summer & 13.8 & 19.6 & 8.5 & 43.5 & 510.0 & 6.5 \\
\hline Fall & 7.5 & 17.4 & 0.0 & 35.2 & $1,100.0$ & 1.4 \\
\hline \multicolumn{7}{|c|}{ Flows at $25.9 \mathrm{~m}^{3} / \mathrm{s}( \pm 10 \%)$} \\
\hline Spring & 6.7 & 8.6 & 5.2 & 7.1 & 14.0 & 4.3 \\
\hline Summer & 15.1 & 19.6 & 10.1 & 59.5 & 310.0 & 13.0 \\
\hline Fall & 7.0 & 12.9 & 1.9 & 30.9 & 340.0 & 1.9 \\
\hline \multicolumn{7}{|c|}{ Flows at $49.3 \mathrm{~m}^{3} / \mathrm{s}( \pm 10 \%)$} \\
\hline Spring & 7.4 & 11.1 & 4.8 & 8.7 & 22.0 & 2.6 \\
\hline Summer & 12.8 & 16.7 & 10.4 & 45.3 & 140.0 & 6.5 \\
\hline Fall & 7.1 & 12.4 & 3.2 & 130.4 & $1,100.0$ & 9.2 \\
\hline
\end{tabular}




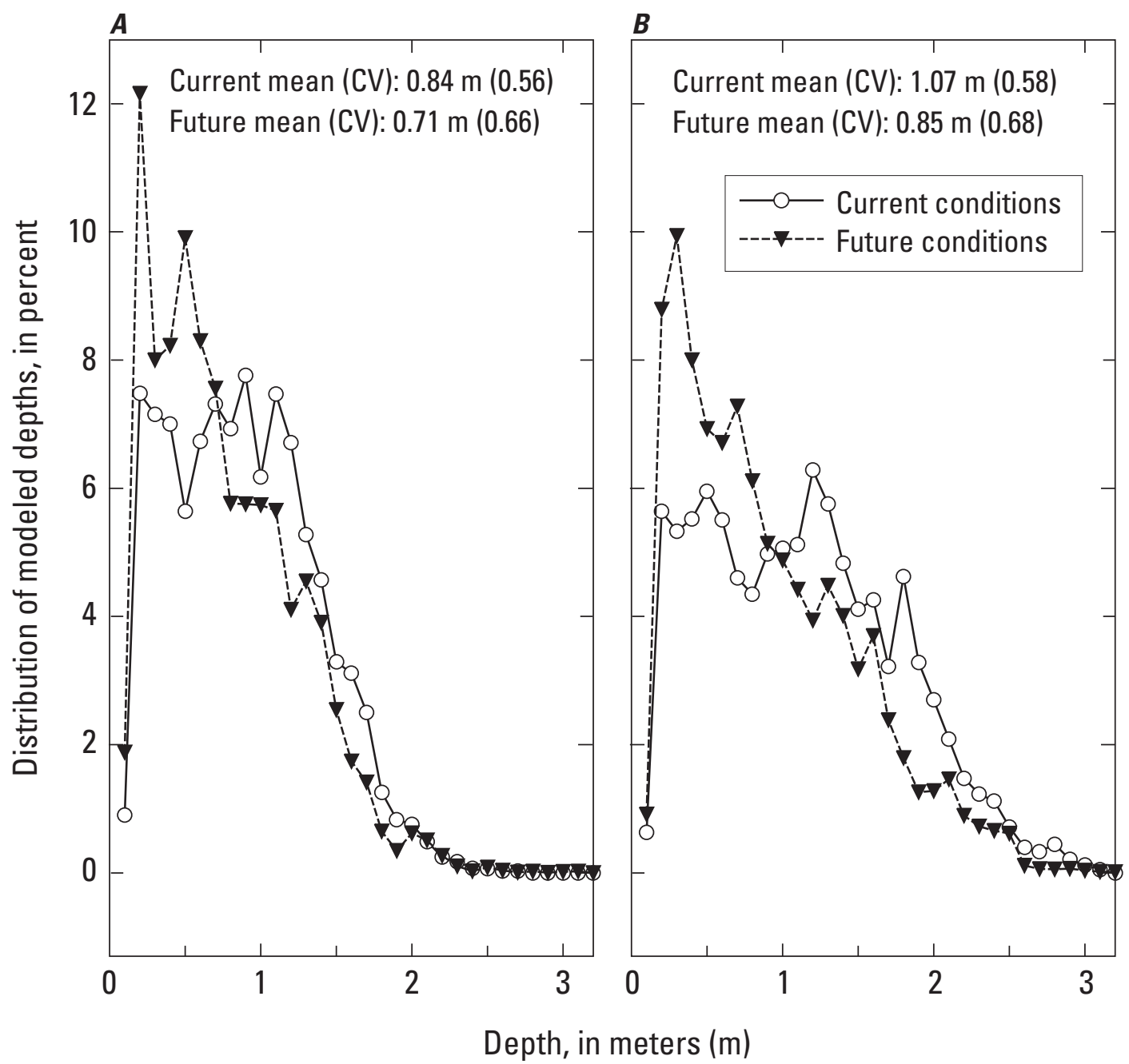

Figure 3. Percentage distributions of modeled depths for flows of $(A) 25.9$ and $(B) 49.3$ cubic meters per second in study reach, White River near Pacific, Washington. (CV, coefficient of variation) 
Although mean depths for both flows were significantly lower under future conditions, the heterogeneity of depths, as measured by the coefficient of variation, were greater under future conditions for both flows (fig. 3). The mean velocity of $0.35 \mathrm{~m} / \mathrm{s}$ predicted for future conditions at a flow of $25.9 \mathrm{~m}^{3} / \mathrm{s}$ was significantly less than the current mean velocity of $0.66 \mathrm{~m} / \mathrm{s}(\mathrm{t}=58.4, \mathrm{p}<0.01)$ (fig. $4 A)$. For a flow of $49.3 \mathrm{~m}^{3} / \mathrm{s}$, the predicted mean velocity of $0.50 \mathrm{~m} / \mathrm{s}$ also was significantly less than the current mean velocity of $1.01 \mathrm{~m} / \mathrm{s}$ $(\mathrm{t}=72.8, \mathrm{p}<0.01)$ (fig. 4B). Like depths, the heterogeneity in predicted velocities for both flows was greater under future conditions (fig. 4).

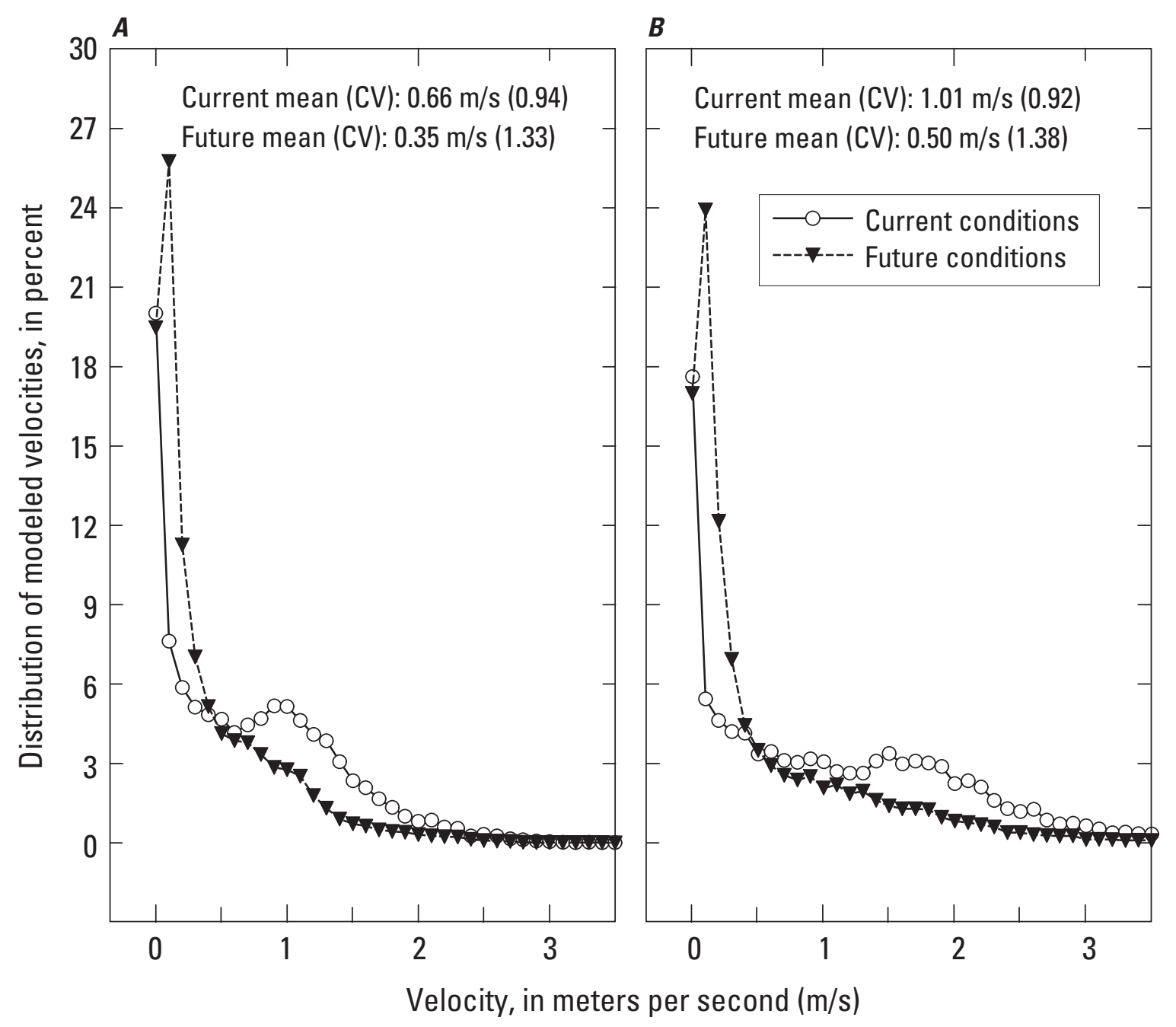

Figure 4. Percentage distributions of modeled velocities for flows of $(A) 25.9$ and $(B) 49.3$ cubic meters per second, in study reach, White River near Pacific, Washington. (CV, coefficient of variation) 


\section{Fish Diet Versus Estimated Drift}

During 2012, juvenile salmonids were sampled once during spring, summer, and fall and the mean percentage composition of their stomach contents were compared with the mean literature-estimated drift composition used in the fish foraging and bioenergetic modeling. Stomach samples were collected from Chinook, coho, and steelhead trout and were summarized across all fish taxa by season. The goal of collecting stomach samples was not to empirically estimate food electivity, but rather to assess if the literature-estimated drift composition was generally representative of what the salmonids in the study reach were eating. The percentage composition of the literature-estimated drift was averaged across flows by season. The captured fish were proportionally consuming more Ephemeroptera (mayflies) than any other aquatic organisms. The percentage of Ephemeroptera in the stomach samples ranged from 52.4 percent in the spring to 30.1 percent in the summer (fig. 5). All stomach samples exhibited between 15 and 36 percent terrestrial insects, which were not included in the literature estimated drift composition. As expected, the highest percentage of terrestrials was measured during the summer (Nakano and Murakami, 2001). Although the absolute percent values for stomach and estimated drift samples differed, the proportion of Diptera and Ephemeroptera typically represented the greatest proportion of stomach and estimated drift samples. In the summer and fall samples, the percent of Hydropsychidae in the stomach samples was higher than the estimated drift samples. The abundance of estimated drifting Hydropsychidae is often low which suggests these fish were engaging in some bottom feeding. Salmonid eggs also were not included in the estimated drift sample, but a limited number were found in stomach samples during the fall sampling, which also may support the bottom feeding possibility. Nevertheless, the high percentage of Diptera and Ephemeroptera known to enter the drift found in the stomach samples as well as the high percentage of terrestrial organisms suggest a high degree of drift feeding.

\section{Energetic Costs and Net Rate of Energy Intake}

For each user defined modeling location within the study reach, energetic costs $(\mathrm{J} / \mathrm{s})$ were calculated for the two flow scenarios of 25.9 and $49.3 \mathrm{~m}^{3} / \mathrm{s}$ for each season under current and future conditions (fig. 6). The highest median energetic costs were always measured under summer conditions for each flow within either current or future management conditions, when foraging efficiency is reduced due to relatively high temperatures and turbidity. Although slightly lower than summer median energetic costs, fall costs were similar and occurred during a period when turbidity was elevated.
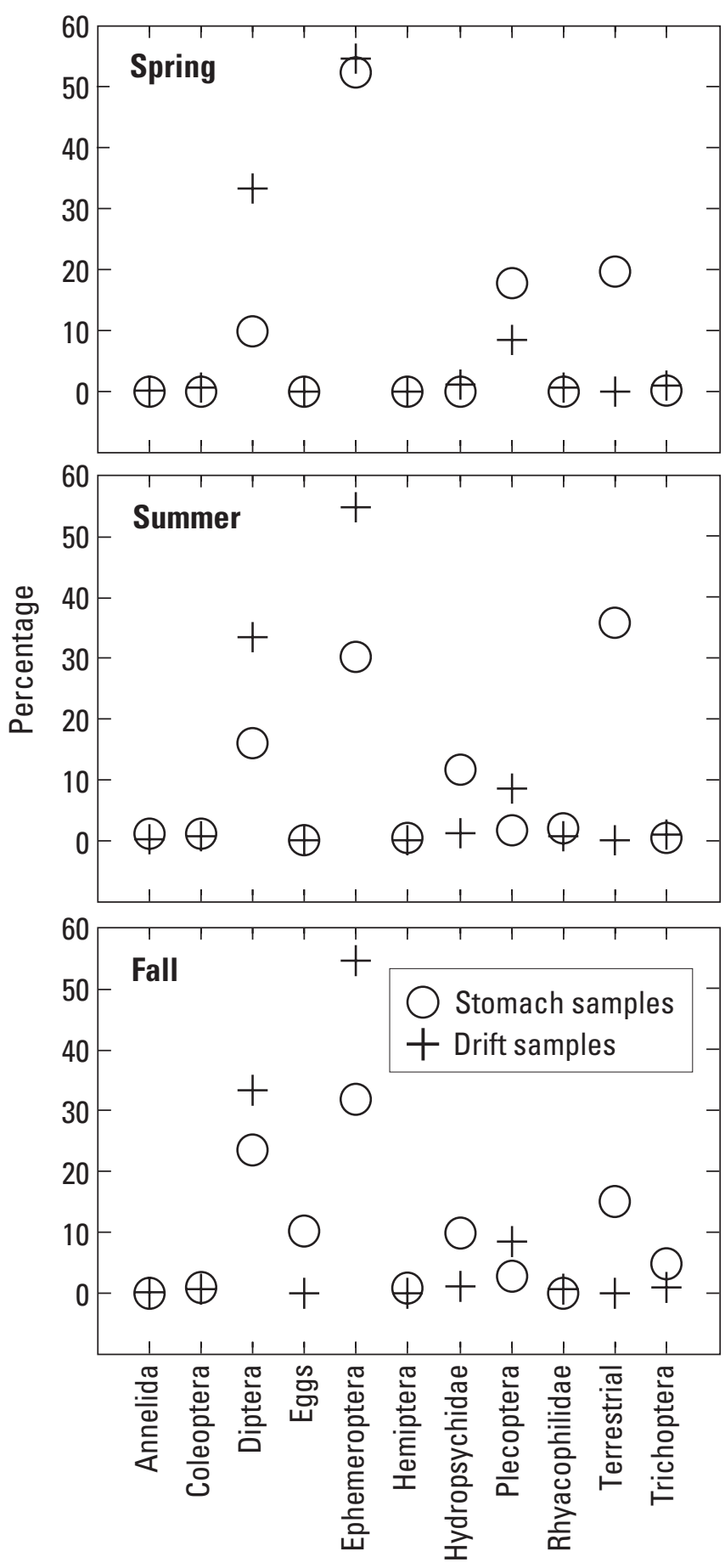

Taxa

Figure 5. Percentage of prey taxa in estimated drift samples and seasonal stomach samples of juvenile salmonids in study reach, White River near Pacific, Washington. The percentage of taxa within the estimated drift was averaged across flows by season. 


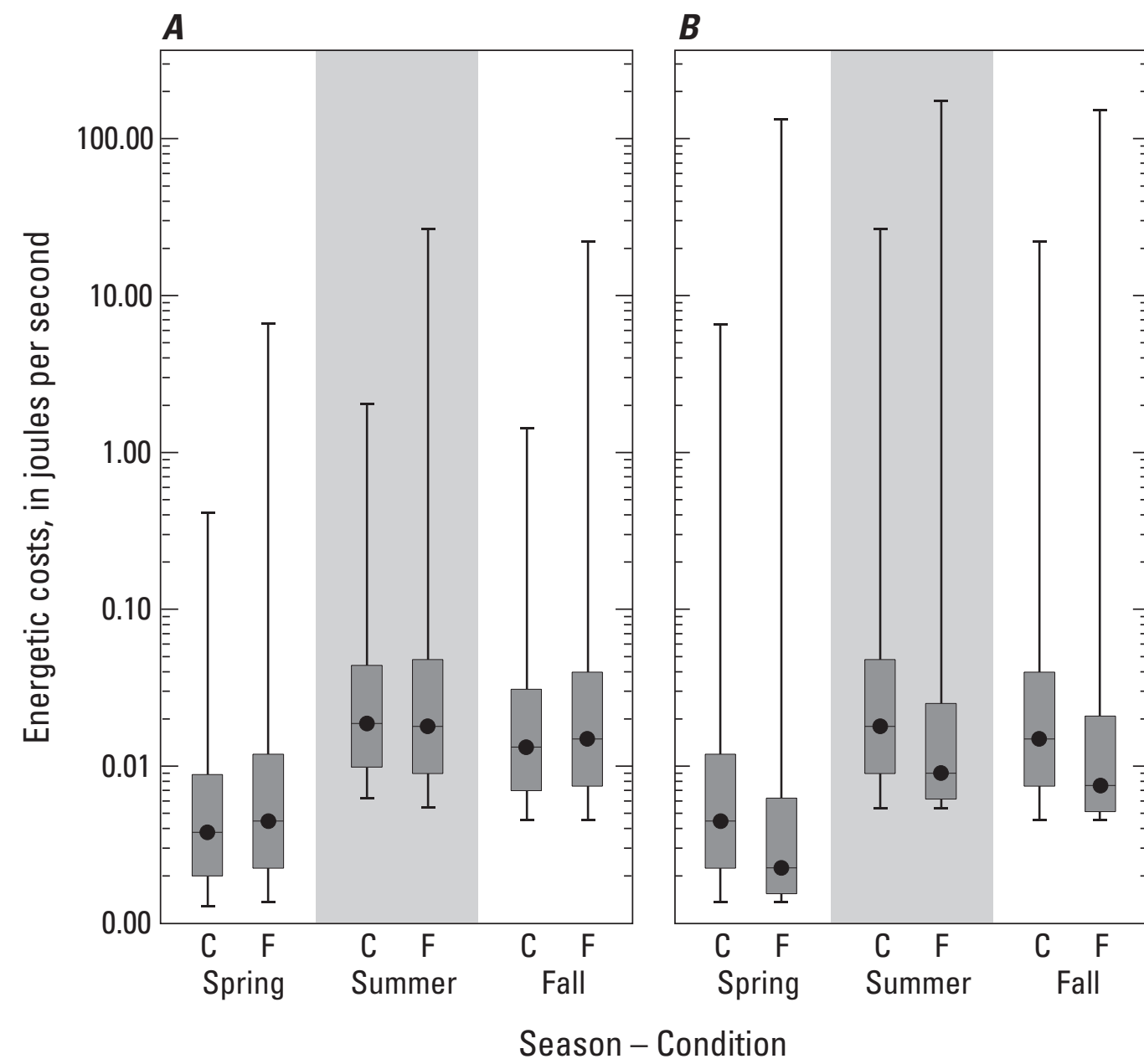

\section{EXPLANATION}

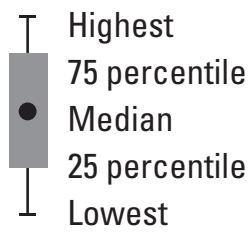

Figure 6. Modeled energetic costs summarized for each season and management condition for flows of $(A) 25.9$ and $(B) 49.3$ cubic meters per second in study reach, White River near Pacific, Washington. Management conditions: $\mathrm{C}=$ Current; $\mathrm{F}=$ Future.

The lowest energetic costs for each flow and management combination were measured during the spring when temperatures and turbidity were relatively low. For the low flow scenario, current and future median energetic costs were similar for each season. However, the range and maximum energetic costs were higher for future conditions than current conditions by season. For the high flow scenario, future conditions also exhibited higher maximum costs than current conditions, but median costs were significantly lower for future conditions by season (Wilcoxan-Rank, p-value $<0.001$ ).

When energetic costs were placed into one of four groups $(<0.01 \mathrm{~J} / \mathrm{s}, 0.01-0.1 \mathrm{~J} / \mathrm{s}, 0.1-1 \mathrm{~J} / \mathrm{s}$, and $>1 \mathrm{~J} / \mathrm{s})$, there was always a significant difference between costs under current and future conditions (fig. 7). For every flow and season combination, the abundance of the most energetically favorable (lowest cost) positions increased under the proposed levee setback relative to the current condition. The highest proportions of the most energetically favorable positions occurred during the spring for both flow scenarios. For the low flow scenario, the proportion of the most energetically favorable positions in spring increased 78 percent under current conditions to 87 percent for future conditions (fig. 7A). For the high flow scenarios, the most energetically favorable positions in spring increased 71 percent under current conditions to 82 percent for future conditions (fig. $7 B$ ). Although spring conditions had the highest proportion of the most energetically favorable positions, the percent increase from current to future conditions was only $12-15$ percent. During summer, the proposed levee setback produced a 92 and 83 percent increase in the most favorable energetic positions for low and high flow scenarios, respectively. The percent increase in the most energetically favorable positions from current to future conditions during the fall ranged from 55 to 59 percent. 
A

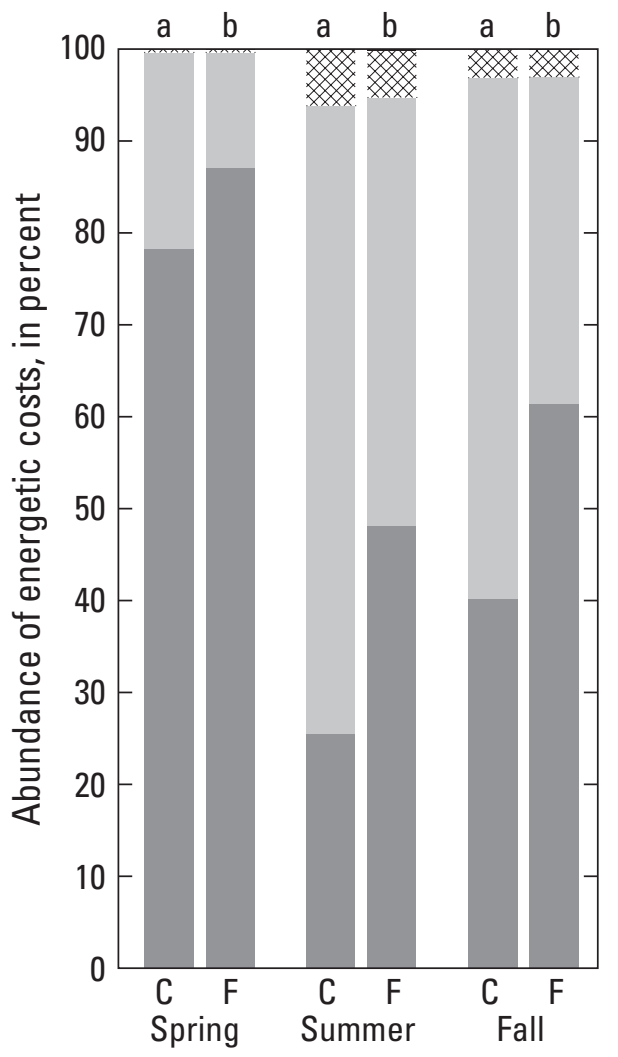

B

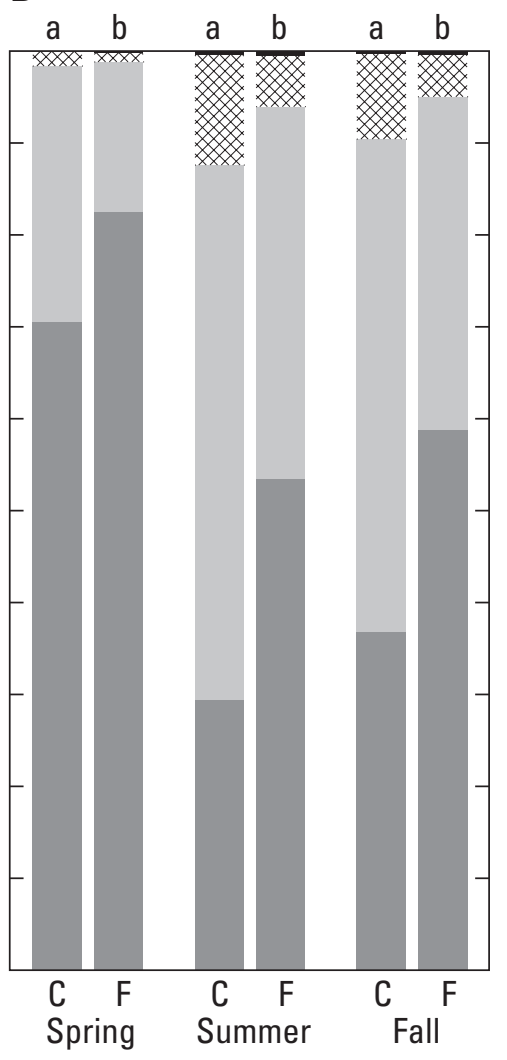

\section{EXPLANATION}

Cost, in joules per second

Lowest

$<0.01$

$0.01-0.1$

$x+x) 0.1-1.0$

$>1$

Highest

\section{Season - Condition}

Figure 7. Percentage abundance of modeled energetic costs (joules per second) summarized within four groups from lowest to highest costs for current and future conditions by season for flows of $(A) 25.9$ and $(B)$ 49.3 cubic meters per second in study reach, White River near Pacific, Washington. Management conditions: $\mathrm{C}=$ Current; $\mathrm{F}=$ Future. Significant difference at the $p<0.05$ level within a season-condition combination at each flow are indicated by dissimilar letter ( $a$ and $b$ ).

The NREI also was calculated for each modeled cell (fig. 8). For the low flow scenario, differences between median NREI for current and future conditions were variable between seasons but the median values were always positive, indicating positive growth potential. The median NREI for future conditions was significantly higher than current conditions in the spring, significantly less than current conditions during the fall, and not significantly different from current conditions in the summer. The maximum NREI values were consistent between current and future conditions by season and was highest in the spring $(16 \mathrm{~J} / \mathrm{s})$ and lowest ( 6 and $5 \mathrm{~J} / \mathrm{s})$ in the summer (fig. $8 A$ ). All of the minimum NREI values were negative indicating negative growth potential. The lowest value was measured for future conditions in the summer
$(-108 \mathrm{~J} / \mathrm{s})$. For the low flow scenario in all seasons, modeled cells with the lowest NREI were for future conditions.

Unlike median NREI values for the low flow scenario, there were significant increases in median NREI values for all of the future conditions relative to current conditions for the high flow scenario (fig. $8 B$ ). The largest increase between current and future conditions occurred in the spring where NREI increased from 0.01 to $0.36 \mathrm{~J} / \mathrm{s}$. Similar to the lower flow results, maximum NREI values were similar between current and future conditions by season, and the maximum values also were measured in the spring $(17 \mathrm{~J} / \mathrm{s})$. Additionally, similar to the low flow results, the minimum NREI values were measured for future conditions for each season and were lowest $(-180 \mathrm{~J} / \mathrm{s})$ for future conditions in the summer. 


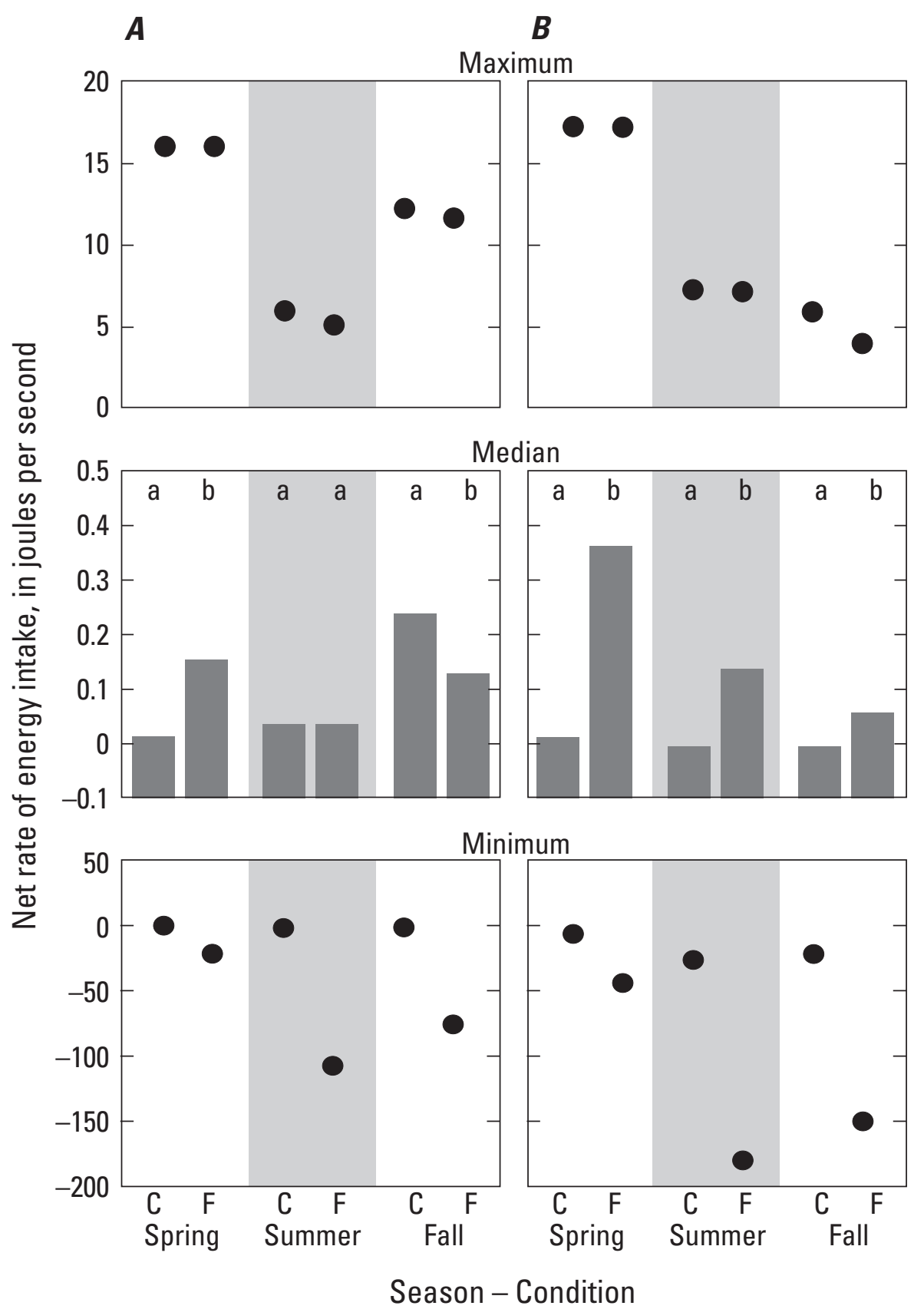

Figure 8. Modeled maximum (dot), median (bar), and minimum (dot) net rate of energy intake (NREI) summarized for each season and management combination for flows of $(A) 25.9$ and $(B) 49.3$ cubic meters per second in study reach, White River near Pacific, Washington. Significant difference at the $p<0.05$ level within a season-condition combination at each flow are indicated by dissimilar letter ( $a$ and $b$ ). 
For each flow, season, and management condition, modeled cells were characterized as having either positive or negative NREI. Positive values are necessary to maintain a fish's weight. These data were summarized as percent abundance of positive NREI positions and compared by flow and season between current and future conditions (fig. 9). For both flow scenarios and each season, the percentage of modeled cells with positive NREI were always significantly higher for future conditions based on Chi-square tests. The abundance of positive NREI model cells were highest in the spring for both flow scenarios and ranged from 88 percent for current conditions and flows of $49.3 \mathrm{~m}^{3} / \mathrm{s}$ to 95 percent for future conditions and flows of $25.9 \mathrm{~m}^{3} / \mathrm{s}$. While the abundance of positive NREI model cells were lower during the summer and fall, it was during these seasons that the greatest increase in the abundance of positive NREI cells between current and future conditions occurred. For the low flow scenario, the bioenergetics model predicted a 32 and 33 percent increase in positive NREI cells for the summer and fall seasons, respectively (fig. 9A). A slightly larger increase in positive NREI cells was simulated for the high flow scenario; the model predicted a 36 percent increase in fall and a 38 percent increase in the summer (fig. $9 B$ ).

\section{Discussion}

It has been suggested that levee setbacks, such as that proposed for the White River, have a high probability of biological success which can occur in a relatively short period of time in the Pacific Northwest (Roni and others, 2012; Bellmore and others, 2013). Levee setback restoration projects similar to the one proposed in this study require detailed physical surveys and hydraulic modeling efforts to ensure, as much as possible, that future flood reduction goals are met. The detailed physical and hydraulic modeling done as part of the engineering design work for this and other projects of this type provide the initial framework from which the energetic assessment presented in this study could be made.

Although some of the modeling framework for this study was in place as a result of the engineering design work, a number of data needs were not available and could not be collected due to resource limitations and to the inherent limitation of working in a highly turbid glacial-fed river that limits the ability to perform many traditional observational studies. The literature estimated macroinvertebrate drift used for this study was assumed to be represented by drift data from rivers with similar hydrologic, geographic, and geomorphic features. Observations described in the literature (Gammon, 1970; Ciborowksi and others, 1977; Rosenberg and Wiens, 1978; Ryan, 1991; Shaw and Richardson, 2001; Berry and others, 2003), suggesting that increases in sediment load influence drift densities, were used to modify the literature based drift densities in response to the changes in turbidity measured in the study reach. It is unclear if the response of drifting macroinvertebrates to the short term changes in sediment measured by these studies translate to glacial-fed

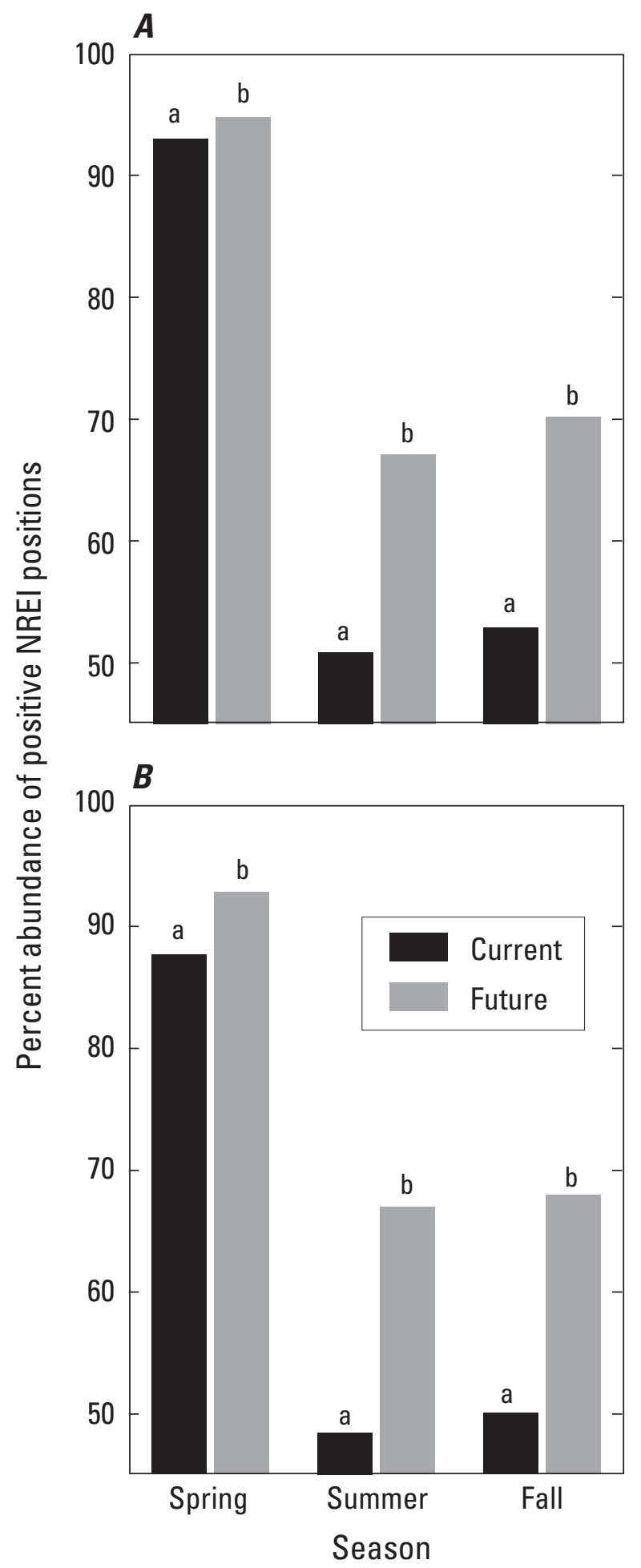

Figure 9. Percent abundance of modeled positive net rate of energy intake (NREI) positions within the study reach under current and future conditions for flows of (A) 25.9 and $(B) 49.3$ cubic meters per second in study reach, White River near Pacific, Washington. Significant difference at the $p<0.05$ level within a season-condition combination at each flow are indicated by dissimilar letter (a and $b$ ). 
rivers that have a more consistent seasonal change in levels of sediment. Although drift feeding fish are known to be selective in their diets (Bisson, 1978; Rader, 1997), at the taxonomic scale used for this study, the percent composition of aquatic macroinvertebrates in the literature estimated drift data set for the spring, summer, and fall periods were considered to be reasonable and acceptable for comparing current with future levee setback conditions.

Though not included in the estimated drift data input, future modeling efforts should consider incorporating terrestrial food source in the drift dispersion and energetics portions of the model, given that adult terrestrial insects were found in the stomachs of some fish and are known to have very high caloric value. Terrestrial organisms could potentially be incorporated into the model by systematically introducing terrestrial invertebrates into water surface cells of the model and controlling the entry rate, settling velocities and time near the bed parameters used in the drift dispersion component of the model. The incorporation of this source of food could add a substantial amount of energy to this system. Under current conditions, terrestrial input is likely to be transported downstream rapidly and be less available to drift feeding fish that are forced to occupy deep or high velocity locations in the river. Under future conditions, terrestrial input is likely to enter areas of slow velocities or shallow areas where drift feeding salmonids are able to see these organisms. Salmon eggs also were not included in the model and were found in fall stomach samples. Although salmonids are typically drift feeders, they do occasionally forage off the bottom (McLaughlin and others, 1994; Fausch and others, 1997; Tunney and Steingrimsson, 2012). It is not clear if these fish were bottom feeding or if they were drift feeding on dislodged eggs during this time. Like the terrestrial insects, a refinement of the drift dispersion model to account for eggs in the drift could be considered.

Turbidity levels in the river were typical of a glacial-fed river: low in the spring and high in the fall. The foraging efficiency of salmonids is greatly affected by levels of turbidity. Laboratory studies have measured salmonid prey capture efficiencies of 80-100 percent when turbidity levels are between 5 and 10 FNUs, which is similar to the values measured during the spring. As turbidity increased to 50 FNUs, capture efficiencies in laboratory studies dropped 10-40 percent and above 130 FNUs, capture efficiencies were almost non-existent (Berg and Northcote, 1985; Barrett and others, 1992; Sweka and Harman, 2001a, 2001b; Harvey and White, 2008). Based on these laboratory studies and the levels of turbidity measured during this study, it is likely that salmonid prey capture efficiencies can be very low to non-existent during summer and fall when maximum turbidity levels can be very high. An effort was made to incorporate the effect of increased turbidity in the summer and fall within the bioenergetics model by systematically reducing capture efficiencies based on mean seasonal turbidity values.
As noted in section, Methods, input data for the fish foraging portion of the model was described as a "typical" juvenile salmonid. Although the literature suggests that different species of salmonids prefer different types of microhabitat as a result of differences in morphology and foraging efficiency in different velocities (Hartman, 1965; Bisson and others, 1988; Bugert and Bjornn, 1991; Bremset and Berg, 1999), Piccolo and others (2008) found juvenile coho and steelhead prey detection and capture was similar across a gradient of velocities. Piccolo and others (2008) suggest that the influence of changes in velocity may be similar across all drift feeding salmonids. For this study, a similar assumption was made regarding the effects of changes in velocity, as well as turbidity, on the percentage of available prey captured. To compare the potential differences between current hydraulic and geomorphic conditions and hypothetical future conditions, it was determined that the trade-off between a generalized salmonid and species specific information was appropriate. Ultimately, the value of this modeling study will be the refinement of the model structure and sensitivity of specific input data based on comparisons of modeled and actual results.

The results from the $2 \mathrm{D}$ hydraulic model produced the results one would expect by widening a river floodplain and keeping discharge constant. For both flow scenarios (25.9 and $49.3 \mathrm{~m}^{3} / \mathrm{s}$ ), average depths and velocities were significantly lower for the future conditions. It is difficult to identify a generalized specific optimal depth for juvenile salmonids, but Raleigh and others (1986) suggest that juvenile Chinook prefer depths of $0.24-0.91 \mathrm{~m}$. For both flow scenarios, mean depths for current conditions were at the upper end or above this optimal range, whereas predicted future depths were within Raleigh and others (1986) optimal range (fig. 3). Similar to depth, salmonid velocity preferences are variable and are dependent upon many factors. However, current mean velocities were generally at or above velocities preferred by juvenile salmonids whereas future mean velocities were within the range of acceptable velocities (fig. 4) (Raleigh and others, 1986; Shirvell, 1994). An increase in the abundance of low velocity and shallower waters would be expected to have a benefit for juvenile salmonids (Bisson and others, 1988; Shirvell, 1990; Sandercock, 1991; Fausch, 1993). In the glacially fed Taku River, Murphy and others (1989) found that velocity was a more important factor in habitat selection than turbidity. An increase in the abundance of lower velocity side channels have been shown to be beneficial to juvenile coho (Tschaplinski and Hartman, 1983) and are suspected to be beneficial to juvenile spring Chinook, particularly during high winter flows (Swales and Levings, 1989).

Of equal importance, is the increase in the variance in depths and velocities resulting from future conditions. This increased variability results in increased habitat heterogeneity, that in turn has the potential to increase suitable habitats 
for a greater diversity of life stages of salmonids, increase the rate of photosynthesis in shallow low velocity areas by reducing turbidity, and increase diversity and density of macroinvertebrates for salmonids to feed upon (Salo and others, 1986; Ahearn and others, 2006; Grosholz and Gallo, 2006). Moreover, the increased variability likely persists over a range of flows indicating the likelihood that some area will have preferred hydraulic conditions at any flow.

Across all flows measured during the study, maximum daily temperatures were below lethal limits for salmon and steelhead and were often close to optimal temperatures (Richter and Kolmes, 2005). However, many of the literaturebased optimal and threshold temperatures do not provide a mechanism for altering these values based on physiological changes brought about by shifts in flow and food delivery that may offset or accentuate the effects of changes in temperature. For this study, the measured mean daily temperatures in summer were similar to optimal levels for Chinook reported in the literature (Richter and Kolmes, 2005), although energetic costs (fig. 6) were the highest and NREI (fig. 8) the lowest during this time. The summer also had the lowest percentage of low energetic cost (fig. 7) and positive growth (fig. 9) positions for current and future conditions for both flow scenarios. Although temperatures appeared to be at optimal levels, turbidity levels were very high which would limit the reaction distance and ability of fish to capture drifting prey resulting in decreased NREI during this time. Turbidity also was very high in the fall, but temperatures were lower which would reduce metabolic demands resulting in the slight improvement in energetic costs (figs. 6 and 7) and NREI (figs. 8 and 9) over summer conditions. Spring was clearly the period of time with the lowest costs (figs. 6 and 7) and highest NREI (figs. 8 and 9). The measured model responses in the spring could be attributed to the limited turbidity and an increased foraging efficiency or ontogenetic shifts in habitat and diet preferences that can occur rapidly during the spring for some salmonids. However, drift densities used in the model during the spring were generally lower than those in summer and fall suggesting that the ability to see prey is critical.

For high and low flow scenarios, future conditions after the levee setback improved in terms of reduced energetic costs (fig. 7) and increased NREI (fig. 8) during all seasons. The greatest relative improvement occurred in the summer. An increase in the abundance of low energetic cost and high NREI positions is likely the result of a significant reduction in stream velocity and an increase in velocity heterogeneity observed for both flow scenarios after the levee setback. It is important to remember that the same hypothetical drift density data sets were used for each unique combination of current and future conditions characterized for each flow and season to calculate NREI. It is highly unlikely that drift densities will remain the same as they are currently modeled after the levee setback has reconnected the main channel with its historical floodplain. Previous studies have indicated that floodplain side channels can have 1 to 2 orders of magnitude greater invertebrate production than in the main channel (Gladden and Smock, 1990). This increase is the result of increased diversity of habitat types suitable for primary and secondary production. Results from the hydraulic model suggest an increase in the variability of depths and velocities ideally suited for increased macroinvertebrate production. In addition, terrestrial invertebrate input is likely to increase as channels form through forested areas. Given the potential of dramatically higher drift densities resulting after the levee setback, the difference between current and future modeled levels of NREI presented in this study would likely be much greater.

For anadromous salmonids, it has been suggested that a biological trade-off between restoration efforts that produce habitat for a few large fish or habitat that is suitable for numerous smaller fish may exist. Roni and others (2006) suggested that larger out-migrating salmonids (smolts) from rivers with a limited number of very high NREI locations indicated better habitat quality since size at migration is correlated with greater ocean survival. Rosenfeld and others (2008) suggest the benefits of larger size smolts have to be balanced against the costs of lower abundance. They suggest that more opportunities for positive growth may be better than a few ideal habitat locations (high NREI) when territorial behavior between a few larger fish force numerous smaller fish into locations of negative growth. The results of this study demonstrate a significant increase in the abundance of positive fish growth ( $>0 \mathrm{NREI}$ ) locations within the study reach as a result of the levee setback. Although maximum values of NREI were generally similar between current and future conditions for each flow and season combination, it is likely that increases in drift densities of post levee setback macroinvertebrate would increase maximum NREI values resulting in both an increase in the number of positive growth positions and an increase in maximum NREI values.

Traditional approaches towards assessing habitat restoration efforts have focused on increasing the abundance of "optimal" levels of physical attributes like depth or velocity, based on published or field-based habitat preferences. These approaches infer a direct correlation between available habitat and production. Rosenfeld and Ptolemy (2012) found that traditional habitat and flow studies can systematically (and incorrectly) predict optimal habitat conditions when flows are inadequate for delivering food resources to the suggested optimal habitats. Like traditional habitat suitability indices, the modeling approach presented here made a number of assumptions. However, traditional habitat suitability based approaches assume that a higher density of fish occupying a particular habitat type implies these fish prefer the conditions found in that habitat, which may be inaccurate. 
Many salmonids develop a strong dominance hierarchy which often results in many individuals being displaced from their energetically preferred habitat. This noted fish density assumption presents potential interpretive limitations, particularly if one is interested in evaluating the energetic benefits of a proposed habitat restoration project on fisheries productivity. The hydraulic and bioenergetics framework used to evaluate the proposed White River levee setback suggests a significant increase in energetically favorable positions may occur for the flows examined as a result of this project. This process-based framework offers a means for advancing our understanding of how hydraulic and geomorphic changes may affect riverine ecosystems.

\section{Conclusions}

Watershed restoration is the focus of many resource managers and can include a multitude of restoration actions each with specific restoration goals, response times, and rates of success. In the case of the White River flowing through the cities of Pacific and Sumner, Washington, a levee setback has been proposed to reconnect the river with its historical floodplain to help reduce flood risks as well as provide increased habitat for federally listed species of salmonids. It has been suggested that these types of restoration efforts have a high probability of biological success and can occur in a relatively short period of time within the Pacific Northwest. The results of the modeling presented here demonstrate a significant increase of up to 92 percent of low energetic cost positions and up to 36 percent of high net rate of energy intake positions within the study reach after constructing the proposed levee setback. This novel modeling process that considers both hydraulics and energetics for evaluating the potential fisheries benefits of reconnecting a river to its historical floodplain is ideally suited for assessing the fisheries benefits from structural changes in river channels. By incorporating an energetics component into the hydraulic assessment, the presented approach also helps address some of the limitations associated with traditional habitat availability approaches.

\section{Acknowledgments}

We would like to thank John Hayes of the Cawthron Institute, New Zeeland, and Lon Kelly of the Bureau of Reclamation for their help with the stream tube, invertebrate drift, and fish foraging models and the field crews of King County's Water and Land Resources Division, Seattle, Washington for help collecting fish stomach samples. This project was funded by the U.S. Geological Survey's Cooperative Water Program, Washington Water Science Center, Tacoma, Washington, and King County's Water and Land Resources Division, Seattle, Washington.

\section{References Cited}

Ahearn, D.S., Viers, J.H., Mount, J.F., and Dahlgren, R.A., 2006, Priming the productivity pump — flood pulse driven trends in suspended algal biomass distribution across a restored floodplain: Freshwater Biology, v. 51, p. 1,417-1,433.

Amoros, C., and Bornette, G., 2002, Connectivity and biocomplexity in water bodies of riverine floodplains: Freshwater Biology, v., 47, p. 761-776.

Anderson, C.A., 2005, Turbidity (ver. 2.1): U.S. Geological Survey Techniques of Water-Resources Investigations, book 9, chap. A6, sec. 6.7 .

Barrett, J.C., Grossman, G.D., and Rosenfeld, J., 1992, Turbidity-induced changes in reactive distance of rainbow trout: Transactions of the American Fisheries Society, v. 121, p. $437-443$.

Beechie, T.J., Beamer, E.M., and Wasserman, L., 1994, Estimating coho salmon rearing habitat and smolt production losses in a large river basin, and implications for habitat restoration: North American Journal Fisheries Management, v. 14, p. 797-811.

Beechie, T.J., Imaki, H., Greene, J., Wade, A., Wu, H., Pess, G., Roni, P., Kimball, J., Stanford, J., Kiffney, P., and Mantua, N., 2012, Restoring salmon habitat for a changing climate: River Research and Applications, v. 29, p. 939-960.

Bellmore, J.R., Baxter, C.V., Martens, K., and Connolly, P.J., 2013, The floodplain food web mosaic — a study of its importance to salmon and steelhead with implications for their recovery: Ecological Applications, v. 23, p. 189-207.

Bellmore, J.R., Baxter, C.V., Ray, A.M., Denny, L., Tardy, K., and Galloway, E., 2012, Assessing the potential for salmon recovery via floodplain restoration - a multitrophic level comparison of dredge-mined to reference segments: Environmental Management, v. 49, p. 734-750.

Berg, L., and Northcote, T.G., 1985, Changes in territorial, gill-flaring, and feeding behavior in juvenile coho salmon (Oncorhynchus kisutch) following short-term pulses of suspended sediment: Canadian Journal of Fisheries and Aquatic Sciences, v. 42, p. 1,410-1,417.

Bernhardt, E.S., Palmer, M.A., Allan, J.D., Alexander, G., Barnas, K., Brooks, S., Carr, J., Clayton, S., Dahm, C., Follstad-Shah, J., Galat, D., Gloss, S., Goodwin, P., Hart, D., Hassett, B., Jenkinson, R., Katz, S., Kondolf, G.M., Lake, P.S., Lave, R., Meyer, J.L., O’Donnell, T.K., Pagano, L., Powell, B., and Sudduth, E., 2005, Synthesizing U.S. river restoration efforts: Science, v. 308 , p. 636-637. 
Berry, W., Rubinstein, N., Melzian, B., and Hill, B., 2003, The biological effects of suspended and bedded sediment (SABS) in aquatic systems - a review: Rhode Island, U.S. Environmental Protection Agency, Office of Research and Development, National Health and Environmental Effects Laboratory, Atlantic Ecology Division, Narragansett, Internal Report, $58 \mathrm{p}$.

Bisson, P., 1978, Diel food selection by two sizes of rainbow trout (Salmo gairdneri) in and experimental stream: Journal of the Fisheries Research Board of Canada, v. 35, p. 971-975.

Bisson, P., Sullivan, K., and Nielsen, J.L., 1988, Channel hydraulics, habitat use, and body form of juvenile coho salmon, steelhead, and cutthroat trout in streams: Transactions of the American Fisheries Society, v. 117, p. 262-273.

Bremset, G., and Berg, O., 1999, Three-dimensional microhabitat use by young pool-dwelling Atlantic salmon and brown trout: Animal Behaviour, v. 58, p. 1,047-1,059.

Brown, A.G., 2002, Learning from the past-palaeohydrology and paiaeoecology: Freshwater Biology, v. 47, p. 817-829.

Bugert, R.M., and Bjornn, T.D., 1991, Habitat use by steelhead and coho salmon and their responses to predators and cover in laboratory streams: Transactions of the American Fisheries Society, v. 120, p. 486-493.

Buijse, A.D., Coops, H., Staras, M., Jans, L.H., Van Geest, G.J., Grift, R.E., Ibelings, B.W., Oosterherg, W., and Roozen, F.C.J.M., 2002, Restoration strategies for river floodplains along large lowland rivers in Europe: Freshwater Biology, v. 47, p. 889-907.

Bureau of Reclamation, 2005, Stream macroinvertebrate surveys in the Cle Elum and Bumping River watersheds: Boise, Idaho, Storage Dam Fish Passage Study, Yakima Project, Washington, Technical Series No. PN-YDFP-002, $44 \mathrm{p}$.

Cellot, B., 1989, Macroinvertebrate movements in a large European river: Freshwater Biology, v. 22, p. 45-55.

Cellot, B., 1996, Influence of side-arms on aquatic macroinvertebrate drift in the main channel of a large river: Freshwater Biology, v. 35, p. 149-164.

Ciborowski, J.J.H., 1983a, Downstream and lateral transport of nymphs of two mayfly species (Ephemeroptera): Canadian Journal of Fisheries and Aquatic Sciences, v. 40, p. 2,025-2,029.

Ciborowski, J.J.H., 1983b, Influence of current velocity, density, and detritus on drift of two mayfly species (Ephemeroptera): Canadian Journal of Zoology, v. 61, p. 119-125.
Ciborowski, J.J.H., 1987, Dynamics of drift and microdistribution of two mayfly populations - A predictive model: Canadian Journal of Fisheries and Aquatic Science, v. 44 , p. $832-845$.

Ciborowksi, J.J.H., Pointing, P.J., and Corkum, L.D., 1977, The effect of current velocity and sediment on the drift of the mayfly Ephemerella subvaria Mcdunnough: Freshwater Biology, v. 7, p. 567-572.

Clarke, L.R., 2007, Macroinvertebrate Drift in Taneum Creek, Washington-Establishment of Baseline Conditions from 2004 to 2006: U.S. Fish and Wildlife Service, 17 p.

Collins, B.D., and Dunne, T., 1989, Gravel transport, gravel harvesting, and channel-bed degradation in rivers draining the southern Olympic Mountains, Washington, USA: Environmental Geology, v. 13, p. 213-224.

Collins, B.D., Montgomery, D.R., and Sheikh, A.J., 2003, Reconstructing the historical riverine landscape of the Puget Lowland, in Montgomery, D.R., Bolton, S.M., Booth, D.B., and Wall, L., eds., Restoration of Puget Sound Rivers: Seattle, University of Washington Press, p. 79-128.

Copp, G.H., 1989, The habitat diversity and fish reproductive function of floodplain ecosystems: Environmental Biology of Fishes, v. 26, p. 1-27.

Costanza, R., d'Arge, R., de Groot, R., Farber, S., Grasso, M., Hannon, B., Limburg, K., Naeem, S., Oneill, R.V., Paruelo, J., Raskin, R.G., Sutton, P., and van den Belt, M., 1997, The value of the world's ecosystem services and natural capital: Nature, v. 387, p. 253-260.

Czuba, J.A., Czuba, C.R., Magirl, C.S., and Voss, F.D., 2010, Channel-conveyance capacity, channel change, and sediment transport in the lower Puyallup, White, and Carbon Rivers, western Washington: U.S. Geological Survey Scientific Investigations Report 2010-5240, 104 p.

Czuba, J.A., Magirl, C.S., Czuba, C.R., Curran, C.S., Johnson, K.H., Olsen, T.D., Kimball, H.K., and Gish, C.C., 2012, Geomorphic analysis of the river response to sedimentation downstream of Mount Rainier, Washington: U.S. Geological Survey Open-File Report 2012-1242, 134 p.

Dunne, T., 1986, Sediment transport and sedimentation between RMs 5 and 30 along the White River, Washington: Bellevue, Washington, Report prepared for Puget Sound Power and Light Company.

Elliott, J.M., 2002, Time spent in the drift by downstreamdispersing invertebrates in a Lake District stream: Freshwater Biology, v. 47, p. 97-106.

Elliott, J.M., and Davidson, W., 1975, Energy equivalents of oxygen consumption in animal energetics: Oecologia, v. 19, p. 195-201. 
Fausch, K.D., 1993, Experimental analysis of microhabitat selection by juvenile steelhead (Oncorhynchus mykiss) and coho salmon (O. kisutch) in a British Columbia stream: Canadian Journal of Fisheries and Aquatic Science, v. 50, p. $1,198-1,207$.

Fausch, K.D., Nakano, S., and Kitano, S., 1997, Experimentally induced foraging mode shift by sympatric charrs in a Japanese mountain stream: Behavioral Biology, v. 8 , p. $414-420$.

Ford, M.J., 2011, Status review update for Pacific salmon and steelhead listed under the Endangered Species ActPacific Northwest: U.S. Department of Commerce, National Oceanic and Atmospheric Administration Technical Memorandum NMFS-NWFSC-113.

Foster, J.R., 1977, Pulsed gastric lavage —An efficient method of removing the stomach contents of live fish: The Progressive Fish-Culturist, v. 39, p. 166-169.

Gammon, J.R., 1970, The effect of inorganic sediment on stream biota: U.S. Environmental Protection Agency, Water Quality Office, Water Pollution Control Research Series 18050DWC12/70, $141 \mathrm{p}$.

Gibs, J., Wilde, F.D., and Heckathorn, H.A., 2007, Use of multiparameter instruments for routine field measurements (ver. 1.1): U.S. Geological Survey Techniques of WaterResources Investigations, book 9, chap. A6, sec. 6.8., http://pubs.water.usgs.gov/twri9A/.

Gislason, J.C., 1985, Aquatic insect abundance in a regulated stream under fluctuating and stable diel flow patterns: North American Journal of Fish Management, v. 5, p. 39-46.

Gladden, J.E., and Smock, L.A., 1990, Macroinvertebrate distribution and production on the floodplains of two lowland headwater streams: Freshwater Biology, v. 24, p. 533-545.

Good, T.P., Waples, R.S., and Adams, P., 2005, Updated status of federally listed ESUs of West Coast salmon and steelhead: U.S. Department of Commerce, National Oceanic and Atmospheric Administration Technical Memorandum NMFS-NWFSC-66.

Gordon, N.D., McMahon, T.A., and Finlayson, B.L., 1992, Stream hydrology - An introduction for ecologists: New York, John Wiley and Sons, 448 p.

Grosholz, E., and Gallo, E., 2006, The influence of flood cycle and fish predation on invertebrate production on a restored California floodplain: Hydrobiologia, v. 568, p. 91-109.

Gustafson, R.G., Wainwright, T.C., Winans, G.A., Waknitz, F.W., Parker, L.T., and Waples, R.S., 1997, Status review of sockeye salmon from Washington and Oregon: National Oceanic and Atmospheric Administration Technical Memorandum NMFS-NWFSC-33, $282 \mathrm{p}$.
Hall, J.E., Holzer, D.M., and Beechie, T.J., 2007, Predicting river floodplain and lateral channel migration for salmon habitat conservation: Journal of American Water Resources Association, v. 43, p. 786-797.

Hanson, P.C., Johnson, T.B., Schindler, D.E., and Kitchell, J.F., 1997, Fish bioenergetics 3.0 for Windows: University of Wisconsin, Madison Center for Limnology, and University of Wisconsin Sea Grant Institute, 104 p.

Hard, J.J., Myers, J.M., Ford, M.J., Kope, R.G., Pess, G.R., Waples, R.S., Winans, G.A., Berejikian, B.A., Waknitz, F.W., Adams, P.B., Bisson, P.A., Campton, D.E., and Reisenbichler, R., 2007, Status review of Puget Sound steelhead (Oncorhynchus mykiss): U.S. Department of Commerce, National Oceanic and Atmospheric Administration Technical Memorandum NMFSNWFSC-81, $117 \mathrm{p}$.

Hartman, G.F., 1965, The role of behavior in the ecology and interaction of underyearling coho salmon (Oncorhynchus kisutch) and steelhead trout (Salmo gairdneri): Journal of the Fisheries Research Board of Canada, v. 22, p. $1,035-1,081$.

Harvey, B.C., and White, J.L., 2008, Use of benthic prey by salmonids under turbid conditions in a laboratory stream: The American Fisheries Society, v. 137, p. 1,756-1,763.

Hayes, J.W., Goodwin, E., Hay, J., Shearer, K., and Kelly, L., 2012, Minimum flow requirements of trout in the Mataura River - Comparison of traditional habitat and net rate of energy intake modelling: Cawthron Report No. 1957, prepared for Environment Southland.

Hayes, J.W., Hughes, N.F., and Kelly, L.H., 2007, Processbased modelling of invertebrate drift transport, net energy intake and reach carrying capacity for drift-feeding salmonids: Ecological Modelling, v. 207, p. 171-188.

Herrera Environmental Consultants and Northwest Hydraulic Consultants, 2011, RIVERFLO-2D calibration reportLower White River levee setback hydraulic and sediment transport modeling: Seattle, Washington, prepared for King County, Department of Natural Resources and Parks, River and Floodplain Management Section.

Hughes, F.M.R., 1997, Floodplain biogeomorphology: Progress in Physical Geography, v. 21, p. 501-529.

Hughes, N.F., Hayes, J.W., Shearer, K.A., and Young, R.G., 2003, Testing a model of drift-feeding using threedimensional videography of wild brown trout, Salmo trutta, in a New Zealand river: Canadian Journal of Fisheries and Aquatic Sciences, v. 60 , p. 1,462-1,476.

Hydronia, 2015, RiverFlow2D modeling package: Hydronia LLC Web page, accessed at http://www.hydronia.com/. 
International River Interface Cooperative, 2015, iRIC Software, version 2.2: International River Interface Cooperative Web page, accessed at http://i-ric.org/en/index. html.

Johnson, O.W., Ruckelshaus, M.H., Grant, W.S., Waknitz, F.W., Garrett, A.M., Bryant, G.J., Neely, K., and Hard, J.J., 1999, Status review of coastal cutthroat trout from Washington, Oregon, and California: National Oceanic and Atmospheric Administration Technical Memorandum NMFS-NWFSC-37, 292 p.

Johnston, T.A., and Cunjak, R.A., 1999, Dry mass-length relationships for benthic insects-A review with new data from Catamaran Brook, New Brunswick, Canada: Freshwater Biology, v. 41, p. 653-674.

Junk, W.J., Bayley, P.B., and Sparks, R.E., 1989, The flood pulse concept in river-floodplain systems: Canadian Journal of Fisheries and Aquatic Sciences, v. 106, p. 110-127.

Kelly, L.H., Hay, J., Hughes, N.F., Goodwin, E., and Hayes, J.W., 2012, Flow related models for simulating river hydraulics, invertebrate drift transport, and foraging energetics of drift-feeding salmonids - Users guide (version 1.1): Prepared in association with the U.S. Bureau of Land Management and University of Alaska Fairbanks, Cawthron Report No. 922, 31 p.

King County, 2013, 2013 Flood hazard management plan update-King County, Washington: Seattle, Washington, King County Department of Natural Resources and Parks, Water and Land Resources Division, 498 p.

Kondolf, G.M., Piegay, H., and Landon, N., 2002, Channel response to increased and decreased bedload supply from land use change - Contrasts between two catchments: Geomorphology, v. 45, p. 35-51.

Martin, D.J., Wasserman, L.J., Jones, R.P., and Salo, E.O., 1984, Effects of Mount St. Helens eruption on salmon populations and habitat in the Toutle River: Bureau of Reclamation, U.S. Department of the Interior, FRI-UW-8412, $130 \mathrm{p}$.

Matthaei, C., Uehlinger, U.R.S., and Frutiger, A., 1997, Response of benthic invertebrates to natural versus experimental disturbance in a Swiss prealpine river: Freshwater Biology, v. 37, p. 61-77.

McLaughlin, R.L., Grant, J.W.A., and Kramer, D.L., 1994, Foraging movements in relation to morphology, watercolumn use, and diet for recently emerged brook trout (Salvelinus fontinalis) in still-water pools: Canadian Journal of Fish Aquatic Sciences, v. 51, p. 268-279.
Meehan, W.R., 1996, Influence of riparian canopy on macroinvertebrate composition and food habits of juvenile salmonids in several Oregon streams: U.S. Forest Service, Pacific Northwest Research Station, 14 p.

Meyer, E., 1989, The relationship between body length parameters and dry mass in running water invertebrates: Archiv für Hydrobiologie, v. 117, p. 191-203.

Montgomery, D.R., Beamer, E.M., Pess, G.R., and Quinn, T.P., 1999, Channel type and salmonid spawning distribution and abundance: Canadian Journal of Fisheries and Aquatic Sciences, v. 56, p. 377-387.

Murphy, M.L., Heifetz, J., Thedinga, J.F., Johnson, S.W., and Koski, K.V., 1989, Habitat utilization by juvenile Pacific salmon (Oncorhynchus) in the glacial Taku River, southeast Alaska: Canadian Journal of Fisheries and Aquatic Sciences, v. 42, p. 1,521-1,533.

Nakano, S., and Murakami, M., 2001, Reciprocal subsidiesDynamic interdependence between terrestrial and aquatic food webs: Proceedings of the National Academy of Sciences of the United States of America, v. 98, p. 166-170.

National Research Council, 1996, Upstream-Salmon and society in the Pacific Northwest: Washington, D.C., National Academy Press, 452 p.

Opperman, J.J., Luster, R., McKenney, B.A., Roberts, M., and Meadows, A.W., 2010, Ecologically functional floodplains - Connectivity, flow regime, and scale: Journal of American Water Resources Association, v. 46, no. 2, p. 211-226.

Orth, D.J., 1987, Ecological considerations in the development and application of instream flow-habitat models: Regulated Rivers, v. 1, p. 171-181.

Pess, G.R., Morley, S.A., Hall, J.L., and Timm, R.K., 2005, Monitoring floodplain restoration, in Roni, P., ed., Methods for monitoring stream and watershed restoration: Bethesda, Maryland, American Fisheries Society, p. 127-166.

Piccolo, J.J., Hughes, N.F., and Bryant, M.D., 2008, Water velocity influences prey detection and capture by driftfeeding juvenile coho salmon (Oncorhynchus kisutch) and steelhead (Oncorhynchus mykiss irideus): Canadian Journal of Fisheries and Aquatic Sciences, v. 65, p. 266-275.

Pierce County, 2012, Rivers flood hazard management planExecutive proposal: Pierce County, Washington, accessed September 12, 2012, at http://www.co.pierce.wa.us/pc/ services/home/environ/water/wqws/floodhazmgmtplan8. htm. 
Prych, E.A., 1988, Flood-carrying capacities and changes in channels of the lower Puyallup, White, and Carbon Rivers in western Washington: U.S. Geological Survey WaterResources Investigations Report 87-4129, 69 p.

Rader, R.B., 1997, A functional classification of the driftTraits that influence invertebrate availability to salmonids: Canadian Journal of Fisheries and Aquatic Sciences, v. 54, p. 1,211-1,234.

Raleigh, R.F., Miller, W.J., and Nelson, P.C., 1986, Habitat suitability index models and instream flow suitability curves - Chinook salmon: U.S. Fish and Wildlife Service, Biological Report 82(10.122), 64 p.

Richards, K., Brasington, J., and Hughes, F., 2002, Geomorphic dynamics of floodplains-Ecological implications and a potential modeling strategy: Freshwater Biology, v. 47, p. 559-579.

Richter, A., and Kolmes, S.A., 2005, Maximum temperature limits for chinook, coho, and chum salmon, and steelhead trout in the Pacific Northwest: Reviews in Fisheries Sciences, v. 13, p. 23-49.

Rohde, S., Hostmann, M., Peter, A., and Ewald, K.C., 2006, Room for rivers - An integrative search strategy for floodplain restoration: Landscape Urban Plan, v. 78, p. 50-70.

Roni, P., and Beechie, T., eds., 2012, Stream and watershed restoration-A guide to restoring riverine processes and habitats: New Jersey, Wiley-Blackwell, 316 p.

Roni, P., Morley, S.A., Garcia, P., Detrick, C., King, D., and Beamer, E., 2006, Coho salmon smolt production from constructed and natural floodplain habitats: Transactions of the American Fisheries Society, v. 135, p. 1,398-1,408.

Rosenberg, D.M., and Wiens, A.P., 1978, Effects of sediment addition on macrobenthic invertebrates in a northern Canadian river: Water Research, v. 12, p. 753-763.

Rosenfeld, J.S., and Ptolemy, R., 2012, Modelling available habitat versus available energy flux-Do PHABSIM applications that neglect prey abundance underestimate optimal flows for juvenile salmonids?: Canadian Journal of Fisheries and Aquatic Sciences, v. 69, p. 1,920-1,934.

Rosenfeld, J.S., Raeburn, E., Carrier, P.C., and Johnson, R., 2008, Effects of side channel structure on productivity of floodplain habitats for juvenile coho salmon: North American Journal of Fisheries Management, v. 28, p. 1,108-1,119.

Rutherford, J.C., 1994, River mixing: New York, John Wiley and Sons, $347 \mathrm{p}$.
Ryan, P.A., 1991, Environmental effects of sediment on New Zealand streams - A review: New Zealand Journal of Marine and Freshwater Research, v. 25, p. 207-221.

Saltveit, S.J., Haug, I., and Brittain, J.E., 2001, Invertebrate drift in a glacial river and its non-glacial tributary: Freshwater Biology, v. 46, p. 1,777-1,789.

Salo, J., Kalliola, R., Hakkinen, I., Makinen, Y., Niemela, P., Puhakka, M., and Coley, P.D., 1986, River dynamics and the diversity of amazon lowland forest: Nature, v. 322, p. 254-258.

Sandercock, F.K., 1991, Life history of coho salmon, in Groot, C., and Margolis, L., eds., Pacific salmon life histories: Vancouver, University of British Columbia Press, p. $395-445$.

Shaw, E.A., and Richardson, J.S., 2001, Direct and indirect effects of sediment pulse duration on stream invertebrate assemblages and rainbow trout (Oncorhynchus mykiss) growth and survival: Canadian Journal of Fisheries and Aquatic Sciences, v. 58, p. 2,213-2,221.

Shirvell, C.S., 1990, Role of instream rootwads as juvenile coho salmon (Oncorhynchus kisutch) and steelhead trout (O. mykiss) cover habitat under varying streamflows: Canadian Journal of Fisheries and Aquatic Sciences, v. 47, p. 852-861.

Shirvell, C.S., 1994, Effects of changes in streamflow on the microhabitat use and movements of sympatric juvenile coho (Oncorhynchus kisutch) and Chinook salmon (O. tshawytscha) in a natural stream: Canadian Journal of Fisheries and Aquatic Sciences, v. 51, p. 1,644-1,652.

Sigler, J.W., Bjornn, T.C., and Everest, F.H., 1984, Effects of chronic turbidity on density and growth of steelheads and coho salmon: Transactions of the American Fisheries Society, v. 113, p. 142-150.

Smock, L.A., 1980, Relationships between body size and biomass of aquatic insects: Freshwater Biology, v. 10, p. $375-383$.

Sommer, T.R., Nobriga, M.L., Harrell, W.C., Batham, W., and Kimmerer, W.J., 2001, Floodplain rearing of juvenile Chinook salmon-Evidence of enhanced growth and survival: Canadian Journal of Fisheries and Aquatic Sciences, v. 58, p. 325-333.

Stanford, J.A., Gayeski, J.N., Pavlov, D.S., Savvaitova, K.A., and Kuzishchin, K.V., 2002, Biophysical complexity of the Krutogorova River (Kamchatka, Russia): Verhandlungen Internationalen Vereinigung für theoretische und angewandte Limnologie, v. 28, p. 1,354-1,361. 
Stanford, J.A., Lorang, M.S., and Hauer, F.R., 2005, The shifting habitat mosaic of river ecosystems: Verhandlungen Internationalen Vereinigung für theoretische und angewandte Limnologie, v. 29, p. 123-136.

Stark, J.D., Shearer, K.A.S., and Hayes, J.W., 2002, Are aquatic invertebrate drift-densities uniform? Implications for salmonid foraging models: Verhandlungen Internationalen Vereinigung für theoretische und angewandte Limnologie, v. 28, p. 988-991.

Swales, S., and Levings, C.D., 1989, Role of off-channel ponds in the life cycle of coho salmon (Oncorhynchus kisutch) and other juvenile salmonids in the Coldwater River, British Columbia: Canadian Journal of Fisheries and Aquatic Sciences, v. 46, p. 232-242.

Sweka, J.A., and Hartman, K.J., 2001a, Effects of turbidity on prey consumption and growth in brook trout and implications for bioenergetics modeling: Canadian Journal of Fisheries and Aquatic Sciences, v. 58, p. 386-393.

Sweka, J.A., and Hartman, K.J., 2001b, Influence of turbidity on brook trout reactive distance and foraging success: Transactions of the American Fisheries Society, v. 130, p. 138-146.

Systat Software, 2009, SYSTAT Web site: San Jose, California, Systat Software, 13.0, accessed at https:// systatsoftware.com/.

Tockner, K., and Stanford, J.A., 2002, Riverine flood plains - Present state and future trends: Environmental Conservation, v. 29, p. 308-330.
Tschaplinski, P.J., and Hartman, G.F., 1983, Winter distribution of juvenile coho salmon (Oncorhynchus kisutch) before and after logging in Carnation Creek, British Columbia, and some implications for overwinter survival: Canadian Journal of Fisheries and Aquatic Sciences, v. 40, p. $452-461$.

Tunney, T.D., and Steingrimsson, S.O., 2012, Foraging mode variation in three stream-dwelling salmonid fishes: Ecology of Freshwater Fish, v. 21, p. 570-580.

Ulfstrand, S., 1968, Life cycles of benthic insects in lapland streams (Ephemeroptera, Plecoptera, Trichoptera, Diptera, Simuliidae): Oikos, v. 19, p. 167-190.

U.S. Geological Survey, 2015, USGS 12100490 White River at R street near Auburn, WA: U.S. Geological Survey National Water Information System, accessed May 15, 2015, at http://waterdata.usgs.gov/nwis/dv?referred module $=$ sw\&site_no $=12100490$.

Wagner, R.J., Boulger, R.W., Oblinger, C.J., and Smith, B.A., 2006, Guidelines and standard procedures for continuous water-quality monitors-Station operation, record computation, and data reporting: U.S. Geological Survey Techniques and Methods, book 1, chap. D3, 14 p.

Ward, J.V., Tockner, and K., Schiemer, F., 1999, Biodiversity of floodplain river ecosystems-Ecotones and connectivity: Regulated Rivers, v. 15, p. 125-139.

Wills, T.C., Baker, E.A., Nuhfer, A.J., Zorn, T.G., 2006, Response of the benthic macroinvertebrate community in a northern Michigan stream to reduced summer streamflows: River Research and Applications, v. 22, p. 819-836. 
Page intentionally left blank. 


\section{Appendix A. Initial Drift Densities Used in Invertebrate Drift Model}

[Season: Spring (March 21-June 20), Summer (June 21-September 21), Fall (September 22-December 20). Abbreviations: mm, millimeter; $\mathrm{m}^{3} / \mathrm{s}, \mathrm{cubic}^{\mathrm{m}} \mathrm{meter}$ per second ; FNU, Nephelometric Turbidity Unit]

\begin{tabular}{|c|c|c|c|c|c|c|c|c|}
\hline \multirow{3}{*}{ Taxa in drift } & \multirow{3}{*}{$\begin{array}{l}\text { Size class } \\
\quad(\mathrm{mm})\end{array}$} & \multirow{3}{*}{$\begin{array}{r}\text { Turbidity (FNU) } \\
\text { Season }\end{array}$} & \multicolumn{3}{|c|}{$\begin{array}{c}\text { Current and future conditions } \\
\text { at } 25.9 \mathrm{~m}^{3} / \mathrm{s}\end{array}$} & \multicolumn{3}{|c|}{$\begin{array}{l}\text { Current and future conditions } \\
\text { at } 49.3 \mathrm{~m}^{3} / \mathrm{s}\end{array}$} \\
\hline & & & 7.08 & 59.46 & 30.9 & 8.72 & 45.25 & 130.4 \\
\hline & & & Spring & Summer & Fall & Spring & Summer & Fall \\
\hline \multirow[t]{4}{*}{ Annelida } & $1-2$ & & 0.0013 & 0.0018 & 0.0014 & 0.0013 & 0.0014 & 0.0036 \\
\hline & $3-4$ & & 0.0027 & 0.0036 & 0.0028 & 0.0027 & 0.0029 & 0.0073 \\
\hline & $5-6$ & & 0.0004 & 0.0005 & 0.0004 & 0.0004 & 0.0004 & 0.0011 \\
\hline & $7-8$ & & 0.0004 & 0.0005 & 0.0004 & 0.0004 & 0.0004 & 0.0010 \\
\hline \multirow[t]{5}{*}{ Coleoptera } & $1-2$ & & 0.0024 & 0.0032 & 0.0025 & 0.0024 & 0.0026 & 0.0065 \\
\hline & $3-4$ & & 0.0066 & 0.0090 & 0.0070 & 0.0066 & 0.0072 & 0.0182 \\
\hline & $5-6$ & & 0.0083 & 0.0112 & 0.0087 & 0.0083 & 0.0090 & 0.0227 \\
\hline & $7-8$ & & 0.0014 & 0.0019 & 0.0015 & 0.0014 & 0.0015 & 0.0039 \\
\hline & $9-10$ & & 0.0002 & 0.0003 & 0.0003 & 0.0002 & 0.0003 & 0.0007 \\
\hline \multirow[t]{8}{*}{ Diptera } & $1-2$ & & 0.4884 & 0.6640 & 0.5171 & 0.4884 & 0.5305 & 1.3411 \\
\hline & $3-4$ & & 0.4003 & 0.5442 & 0.4238 & 0.4003 & 0.4348 & 1.0992 \\
\hline & $5-6$ & & 0.0984 & 0.1338 & 0.1042 & 0.0984 & 0.1069 & 0.2703 \\
\hline & 7-8 & & 0.0123 & 0.0167 & 0.0130 & 0.0123 & 0.0133 & 0.0337 \\
\hline & $9-10$ & & 0.0068 & 0.0093 & 0.0072 & 0.0068 & 0.0074 & 0.0187 \\
\hline & $11-13$ & & 0.0016 & 0.0021 & 0.0017 & 0.0016 & 0.0017 & 0.0043 \\
\hline & $14-16$ & & 0.0004 & 0.0005 & 0.0004 & 0.0004 & 0.0004 & 0.0010 \\
\hline & $21-24$ & & 0.0003 & 0.0004 & 0.0003 & 0.0003 & 0.0003 & 0.0008 \\
\hline \multirow[t]{6}{*}{ Ephemeroptera } & $1-2$ & & 0.6964 & 0.9468 & 0.7373 & 0.6964 & 0.7564 & 1.9122 \\
\hline & $3-4$ & & 0.8393 & 1.1411 & 0.8887 & 0.8393 & 0.9116 & 2.3047 \\
\hline & $5-6$ & & 0.1018 & 0.1384 & 0.1078 & 0.1018 & 0.1105 & 0.2795 \\
\hline & $7-8$ & & 0.0137 & 0.0187 & 0.0145 & 0.0137 & 0.0149 & 0.0377 \\
\hline & $9-10$ & & 0.0023 & 0.0031 & 0.0024 & 0.0023 & 0.0025 & 0.0063 \\
\hline & $17-20$ & & 0.0011 & 0.0015 & 0.0012 & 0.0011 & 0.0012 & 0.0031 \\
\hline \multirow[t]{8}{*}{ Hydropsychidae } & $1-2$ & & 0.0072 & 0.0097 & 0.0076 & 0.0072 & 0.0078 & 0.0196 \\
\hline & $3-4$ & & 0.0179 & 0.0243 & 0.0189 & 0.0179 & 0.0194 & 0.0491 \\
\hline & $5-6$ & & 0.0056 & 0.0077 & 0.0060 & 0.0056 & 0.0061 & 0.0155 \\
\hline & $7-8$ & & 0.0011 & 0.0015 & 0.0011 & 0.0011 & 0.0012 & 0.0029 \\
\hline & $9-10$ & & 0.0003 & 0.0004 & 0.0003 & 0.0003 & 0.0003 & 0.0007 \\
\hline & $11-13$ & & 0.0006 & 0.0009 & 0.0007 & 0.0006 & 0.0007 & 0.0017 \\
\hline & $14-16$ & & 0.0005 & 0.0006 & 0.0005 & 0.0005 & 0.0005 & 0.0012 \\
\hline & $17-20$ & & 0.0009 & 0.0012 & 0.0009 & 0.0009 & 0.0010 & 0.0024 \\
\hline \multirow[t]{8}{*}{ Plecoptera } & $1-2$ & & 0.0928 & 0.1261 & 0.0982 & 0.0928 & 0.1008 & 0.2547 \\
\hline & $3-4$ & & 0.1137 & 0.1545 & 0.1203 & 0.1137 & 0.1234 & 0.3121 \\
\hline & $5-6$ & & 0.0345 & 0.0469 & 0.0365 & 0.0345 & 0.0375 & 0.0947 \\
\hline & $7-8$ & & 0.0073 & 0.0099 & 0.0077 & 0.0073 & 0.0079 & 0.0199 \\
\hline & $9-10$ & & 0.0023 & 0.0032 & 0.0025 & 0.0023 & 0.0025 & 0.0064 \\
\hline & $11-13$ & & 0.0026 & 0.0035 & 0.0028 & 0.0026 & 0.0028 & 0.0072 \\
\hline & $17-20$ & & 0.0017 & 0.0024 & 0.0018 & 0.0017 & 0.0019 & 0.0048 \\
\hline & $21-24$ & & 0.0012 & 0.0016 & 0.0012 & 0.0012 & 0.0013 & 0.0032 \\
\hline \multirow[t]{6}{*}{ Rhyacophilidae } & $1-2$ & & 0.0039 & 0.0053 & 0.0042 & 0.0039 & 0.0043 & 0.0108 \\
\hline & $3-4$ & & 0.0065 & 0.0089 & 0.0069 & 0.0065 & 0.0071 & 0.0179 \\
\hline & $5-6$ & & 0.0037 & 0.0050 & 0.0039 & 0.0037 & 0.0040 & 0.0101 \\
\hline & $7-8$ & & 0.0040 & 0.0055 & 0.0043 & 0.0040 & 0.0044 & 0.0110 \\
\hline & $9-10$ & & 0.0009 & 0.0012 & 0.0009 & 0.0009 & 0.0010 & 0.0024 \\
\hline & $11-13$ & & 0.0008 & 0.0011 & 0.0008 & 0.0008 & 0.0009 & 0.0022 \\
\hline \multirow[t]{4}{*}{ Trichoptera } & $1-2$ & & 0.0175 & 0.0238 & 0.0185 & 0.0175 & 0.0190 & 0.0481 \\
\hline & $3-4$ & & 0.0088 & 0.0119 & 0.0093 & 0.0088 & 0.0095 & 0.0241 \\
\hline & $5-6$ & & 0.0021 & 0.0029 & 0.0023 & 0.0021 & 0.0023 & 0.0059 \\
\hline & $7-8$ & & 0.0003 & 0.0004 & 0.0003 & 0.0003 & 0.0003 & 0.0007 \\
\hline
\end{tabular}




\section{Appendix B. Invertebrate Attributes Used in Invertebrate Drift Model}

[Abbreviations: g, gram; $\mathrm{m}$, meter; $\mathrm{mm}$, millimeter; $\mathrm{m} / \mathrm{s}$, meter per second; $\mathrm{m}^{2} / \mathrm{s}$, square meter per second; $\mathrm{s}$, second]

\begin{tabular}{|c|c|c|c|c|c|c|}
\hline Taxa in drift & $\begin{array}{l}\text { Size class } \\
\quad(\mathrm{mm})\end{array}$ & $\begin{array}{c}\text { Entry rate into } \\
\text { drift for each } \\
\text { taxa-size class } \\
\text { (number per } \mathrm{m}^{2} / \mathrm{s} \text { ) }\end{array}$ & $\begin{array}{l}\text { Settling velocity } \\
\text { for each } \\
\text { taxa-size class } \\
(\mathrm{m} / \mathrm{s})\end{array}$ & $\begin{array}{l}\text { Time spent near } \\
\text { bed following } \\
\text { near bed release } \\
\text { (s) }\end{array}$ & $\begin{array}{l}\text { Mean length of } \\
\text { taxa-size class } \\
\text { (m) }\end{array}$ & $\begin{array}{l}\text { Dry weight of } \\
\text { taxa-size class } \\
\text { (g) }\end{array}$ \\
\hline \multirow[t]{3}{*}{ Annelida } & $1-2$ & 0.00001 & 0.009 & 3 & 0.0015 & 0.00002 \\
\hline & $3-4$ & 0.0001 & 0.0174 & 3 & 0.0035 & 0.00014 \\
\hline & $5-6$ & 0.00001 & 0.0258 & 3 & 0.0055 & 0.00051 \\
\hline \multirow{4}{*}{ Coleoptera } & $3-4$ & 0.0005 & 0.025 & 6 & 0.0035 & 0.00314 \\
\hline & $5-6$ & 0.0009 & 0.03 & 6 & 0.0055 & 0.00760 \\
\hline & $7-8$ & 0.0013 & 0.02 & 1 & 0.0075 & 0.01423 \\
\hline & $9-10$ & 0.0018 & 0.03 & 1 & 0.0095 & 0.02314 \\
\hline \multirow[t]{4}{*}{ Diptera } & $1-2$ & 0.0004 & 0.0011 & 10 & 0.0015 & 0.00003 \\
\hline & $11-13$ & 0.00001 & 0.0116 & 10 & 0.0120 & 0.00226 \\
\hline & $14-16$ & 0.000006 & 0.0146 & 10 & 0.0150 & 0.00389 \\
\hline & $21-24$ & 0.000006 & 0.0221 & 10 & 0.0225 & 0.00988 \\
\hline \multirow[t]{6}{*}{ Ephemeroptera } & $1-2$ & 0.0035 & 0.0035 & 2 & 0.0015 & 0.00004 \\
\hline & $3-4$ & 0.0028 & 0.00526 & 6 & 0.0035 & 0.00028 \\
\hline & $5-6$ & 0.0021 & 0.00992 & 6 & 0.0055 & 0.00089 \\
\hline & $7-8$ & 0.0015 & 0.01458 & 6 & 0.0075 & 0.00221 \\
\hline & $9-10$ & 0.0008 & 0.01924 & 6 & 0.0095 & 0.00419 \\
\hline & $17-20$ & $9.93 \mathrm{E}-31$ & 0.04021 & 6 & 0.0185 & 0.02720 \\
\hline \multirow[t]{2}{*}{ Hydropsychidae } & $1-2$ & 0.00005 & 0.0067 & 6 & 0.0015 & 0.00002 \\
\hline & $3-4$ & 0.0001 & 0.0077 & 6 & 0.0035 & 0.00014 \\
\hline \multirow{7}{*}{ Plecoptera } & $3-4$ & 0.0004 & 0.0034 & 6 & 0.0035 & 0.00025 \\
\hline & $5-6$ & 0.0003 & 0.0058 & 6 & 0.0055 & 0.00100 \\
\hline & $7-8$ & 0.00006 & 0.0082 & 6 & 0.0075 & 0.00265 \\
\hline & $9-10$ & 0.00002 & 0.0106 & 6 & 0.0095 & 0.00564 \\
\hline & $11-13$ & 0.00008 & 0.0136 & 6 & 0.0120 & 0.01047 \\
\hline & $17-20$ & 0.00001 & 0.0214 & 6 & 0.0185 & 0.04140 \\
\hline & $21-24$ & 0.00001 & 0.0262 & 6 & 0.0225 & 0.08175 \\
\hline \multirow[t]{6}{*}{ Rhyacophilidae } & $1-2$ & 0.0000025 & 0.00069 & 6 & 0.0015 & 0.00002 \\
\hline & $3-4$ & 0.00001 & 0.00129 & 6 & 0.0035 & 0.00014 \\
\hline & $5-6$ & 0.00001 & 0.00189 & 6 & 0.0055 & 0.00051 \\
\hline & $7-8$ & 0.00001 & 0.00249 & 6 & 0.0075 & 0.00125 \\
\hline & $9-10$ & 0.000002 & 0.00309 & 6 & 0.0095 & 0.00250 \\
\hline & $11-13$ & 0.000003 & 0.00384 & 6 & 0.0120 & 0.00442 \\
\hline \multirow[t]{4}{*}{ Trichoptera } & $1-2$ & 0.0007 & 0.0097 & 3 & 0.0015 & 0.00002 \\
\hline & $3-4$ & 0.00015 & 0.0171 & 3 & 0.0035 & 0.00014 \\
\hline & $5-6$ & 0.00009 & 0.0245 & 3 & 0.0055 & 0.00051 \\
\hline & $7-8$ & 0.000015 & 0.0319 & 3 & 0.0075 & 0.00125 \\
\hline
\end{tabular}


Publishing support provided by the U.S. Geological Survey

Science Publishing Network, Tacoma Publishing Service Center

For more information concerning the research in this report, contact the Director, Washington Water Science Center

U.S. Geological Survey

934 Broadway, Suite 300

Tacoma, Washington 98402

http://wa.water.usgs.gov 
